\title{
Forearc uplift rates deduced from sediment cores of two coastal lakes in south-central Chile
}

\author{
Susanne Stefer ${ }^{\mathrm{a}, \mathrm{b}, *}$, Jasper Moernaut $^{\mathrm{c}}$, Daniel Melnick ${ }^{\mathrm{b}, \mathrm{d}}$, Helmut P. Echtler ${ }^{\mathrm{a}, \mathrm{d}}$, Helge W. Arz ${ }^{\mathrm{a}}$, Frank Lamy ${ }^{\mathrm{e}}$, \\ Marc De Batist ${ }^{\mathrm{c}}$, O. Oncken ${ }^{\mathrm{a}}$, Gerald H. Haug b,f \\ a Deutsches GeoForschungsZentrum (GFZ) Potsdam, Germany \\ ${ }^{\mathrm{b}}$ Leibniz Centre for Earth Surface and Climate Studies at the University of Potsdam, Germany \\ ${ }^{c}$ Renard Centre of Marine Geology, Ghent University, Belgium \\ d University of Potsdam, Department of Geosciences, Potsdam, Germany \\ e Alfred-Wegener-Institut für Polar- und Meeresforschung (AWI) Bremerhaven, Germany \\ ${ }^{\mathrm{f}}$ Eidgenössische Technische Hochschule (ETH) Zürich, Switzerland
}

\section{A R T I C L E I N F O}

\section{Article history:}

Received 22 October 2008

Accepted 8 May 2009

Available online 18 May 2009

\section{Keywords:}

Forearc tectonics

Uplift rate

Lago Lanalhue

Lago Lleu Lleu

Arauco Peninsula

Sea-level change

\begin{abstract}
A B S T R A C T
The present paper introduces a new approach for deriving information about local forearc tectonics and related uplift rates based on the study of lake sediments. We investigated two coastal lakes at the south-central Chile margin, lakes Lanalhue and Lleu Lleu, located south of the Arauco Peninsula $\left(38^{\circ} \mathrm{S}\right)$. Both lakes developed within the valleys of ancient rivers that once drained to the Pacific Ocean, being subsequently dammed by rising sills in the late Pleistocene/early Holocene. Seismic profiling and sedimentological analyses of cores from both lakes revealed similar successions consisting of marine to brackish sediments covered by lacustrine deposits. Radiocarbon dating indicates that the marine-lacustrine transition occurred at $8 \mathrm{ka}$ and $8.15 \mathrm{ka}$, respectively. The correlation of this transition with global sea-level curves allowed the calculation of local uplift rates for the Holocene. Uplift rates for the lake basins amount to $0.42 \pm 0.71$ and $0.49 \pm 0.44 \mathrm{~mm} / \mathrm{a}$, respectively, which are consistent with rates determined from a late Pleistocene marine terrace in the area. However, conspicuously higher, though likely transient, vertical movements at $8.83 \pm 2.7 \mathrm{~mm} / \mathrm{a}$ and $11.36 \pm 1.77 \mathrm{~mm} / \mathrm{a}$, respectively, were calculated for the sills that block both lakes nowadays. These barriers are interpreted to be the surface expression of a blind reverse fault associated to the Morguilla fault system, a seismically-active structure that controls uplift and folding along the adjacent Arauco Peninsula.
\end{abstract}

(C) 2009 Elsevier B.V. All rights reserved.

\section{Introduction}

Uplift and subsidence are common phenomena in tectonically active coasts worldwide (e.g. Lajoie, 1986; Hsu, 1992; Chen and Liu, 2000; Antonioli et al., 2006; Rajendran et al., 2008). The analysis and measurement of vertical deformation can provide insight to fundamental tectonic mechanisms and associated crustal responses (e.g. Abbott et al., 1997). The most conventional approach for calculating surface uplift rates at tectonically active margins is the analysis and dating of deformed marine terraces that emerged from the ocean and are nowadays situated above sea level (e.g. Burbank and Anderson, 2001; Keller and Pinter, 2002; Antonioli et al., 2006; Rajendran et al., 2008). These relict shorelines bear evidence of both past sea-level highstands during interglacial/interstadial periods

\footnotetext{
* Corresponding author. Deutsches GeoForschungsZentrum (GFZ), Telegrafenberg, 14473 Potsdam, Germany. Fax: +49 3312881302.

E-mail address: stefers@gfz-potsdam.de (S. Stefer).
}

and of subsequent tectonic uplift. Therefore, if the age and elevation of the marine terrace surfaces and of the paleo-sea level highstands are known, an averaged uplift rate of each marine terrace can be calculated for the period since its formation. However, marine terrace surfaces are ephemeral geomorphic entities whose capacity to record changes in the landscape caused by surface uplift, folding, or faulting, basically depends on the local rate of erosion and deformation, as well as of the local bedrock erodibility (e.g. Anderson et al., 1999). In regions where weak bedrock, high precipitation and low deformation rates coexist, the tectonic record provided by marine terrace surfaces will probably not exceed the past $10^{4}-10^{5}$ years.

In this study, we attempt to use an alternative, novel approach for calculating surface uplift rates using the sediment archives of two coastal lakes from the south-central Chile subduction margin (Fig. 1). We focus on Lago Lanalhue and Lago Lleu Lleu, located south of the Arauco peninsula $\left(38^{\circ} \mathrm{S}\right)$, and combine seismic-reflection profiles, dated sediment cores, and geomorphic field observations to decipher landscape evolution and explore the capacity of these lakes to record coastal tectonic processes. 


\section{Tectonic framework}

\subsection{Regional tectonic and geologic setting}

The Chile margin is formed by oblique convergence between the oceanic Nazca Plate and the South American continent at $\sim 66 \mathrm{~mm} / \mathrm{a}$ (Angermann et al., 1999; Kendrick et al., 2003). Adjacent to the study area, the subducting Nazca Plate is $\sim 32$ Ma old and the Perú-Chile trench is filled by $1.5-2.0 \mathrm{~km}$ of sediments (e.g. Bangs and Cande, 1997). Sediments have filled the trench since the onset of glaciation in the Patagonian Andes ca. 6-5 Ma, leading to a change from erosive to accretionary conditions during the Pliocene, and resulting in the inversion of forearc basins (Bangs and Cande, 1997; Melnick and Echtler, 2006a).

Onshore, this sector of the margin is characterized by four main morphotectonic units (e.g. Melnick and Echtler, 2006b): (1) the Coastal Platform, which is composed of uplifted Cenozoic marine and coastal sedimentary sequences, and where our study region locates, (2) the Coastal Cordillera, which is formed by a Permo-Triassic accretionary complex south of $\sim 38^{\circ} \mathrm{S}$ and a late Paleozoic magmatic arc to the north (Hervé, 1988; Glodny et al., 2005; Glodny et al., 2008b and references therein), (3) the Central Depression, which is made up by

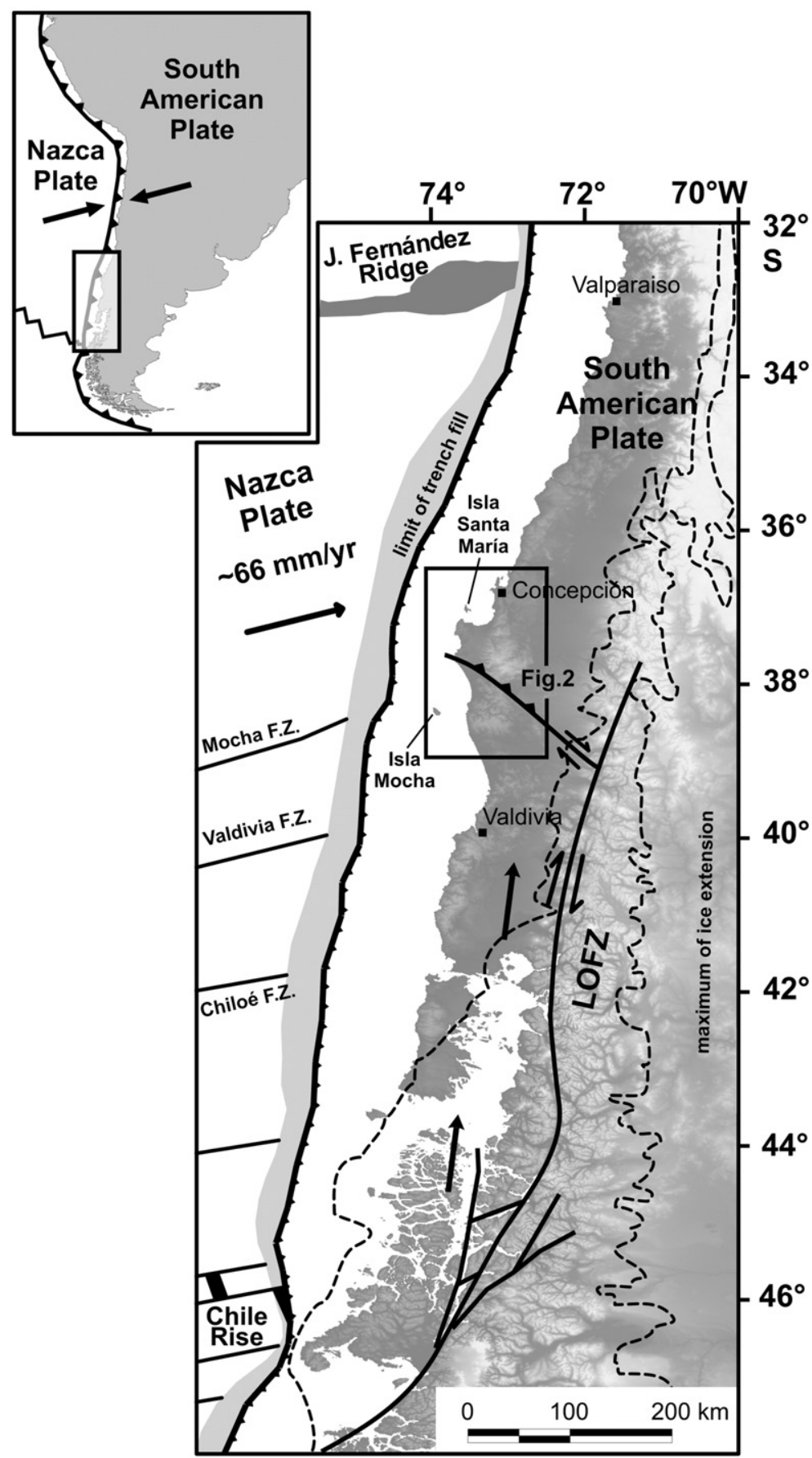

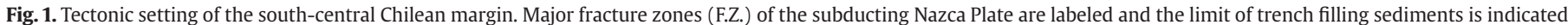

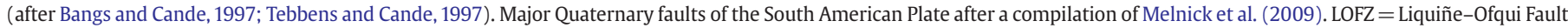

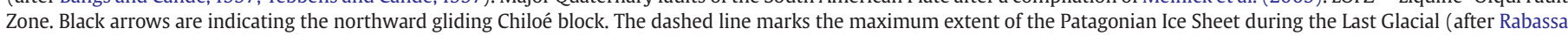
and Clapperton, 1990). 
Oligocene-Miocene volcanic and sedimentary rocks, overlain by Pliocene-Quaternary fluvial-alluvial sediments (Muñoz et al., 2000; Jordan et al., 2001), and (4) the Main Cordillera, which constitutes a Mesozoic-Cenozoic magmatic arc with intra-arc sedimentary basins (Mpodozis and Ramos, 1989).

A first-order discontinuity of the Main Cordillera is the $\mathrm{N}-\mathrm{S}$ trending Liquiñe-Ofqui Fault Zone (LOFZ). This dextral strike-slip discontinuity is mainly a result of oblique plate convergence (Hervé, 1994) and collision of the Chile Rise at its southern end (Nelson et al., 1994). The LOFZ decouples the south-central Chilean forearc, which is suggested to behave as a northward gliding sliver (so-called 'Chiloé block', Fig. 1) by several authors (Cembrano et al., 2002; Rosenau et al., 2006). At its northern edge, this block is bounded by the NW-striking Lanalhue fault system (Glodny et al., 2008a), which splays out from the LOFZ at $\sim 39^{\circ} \mathrm{S}$. Along this fault system, the Chiloe block collides against a buttress formed by the Arauco-Nahuelbuta block resulting in $\sim 6 \mathrm{~mm} / \mathrm{a}$ of margin-parallel shortening (Melnick et al., 2009). Global Positioning System (GPS) data indicate vertical axis counter-clockwise rotations along the northern edge of the Chiloé block, supporting ongoing collision and decoupling of crustal blocks across the Lanalhue fault system (Moreno et al., 2008).

The Lanalhue fault, running along Lanalhue Lake, juxtaposes two distinct units in the metamorphic basement of the Coastal Cordillera. It separates high-pressure metasedimentary rocks and ophiolitic components of the Western Series from high-temperature contact metasedimentary rocks of the Eastern Series (Hervé, 1988). The Morguilla fault runs along the southern flank of the Arauco Peninsula, forming a pronounced, up to 150 -m-high scarp. The height of this scarp decreases toward the southeast where it becomes blanketed by active dunes (Fig. 3). The fault cuts through the western site of Lago Lleu Lleu, juxtaposing metamorphic rocks with Pleistocene sediments of the Cañete surface. The Morguilla and Lanalhue faults appear to be connected west of Lago Lanalhue, where several small ponds are aligned along the fault trace (Fig. 3) (Melnick and Echtler, 2006b).

\subsection{Seismicity, neotectonics, and deformation at the Arauco Peninsula and its vicinity}

The most striking structural feature of the fairly straight southcentral Chile margin is the protruding Arauco Peninsula $\left(\sim 38^{\circ} \mathrm{S}\right.$, Fig. 2). Morphologically, it is defined by the Cordillera de Nahuelbuta in the east, the coastal plain in the west, and the Bío Bío and Imperial Rivers to the north and south $\left(36-38^{\circ} \mathrm{S}\right)$. The peninsula is considered to be an uplifted part of the continental shelf (Kaizuka et al., 1973) that underwent a temporally and spatially discontinuous forearc-basin formation since the late Cretaceous (Melnick and Echtler, 2006a). Since the late Pliocene, Arauco is characterized by constant coastal uplift (Melnick et al., 2009).

The Arauco-Nahuelbuta forearc is located within the overlapping rupture zone of the 1960 Valdivia $\left(M_{\mathrm{W}} 9.5\right)$ and the 1835 Concepción ( $M \sim 8.5)$ megathrust earthquakes (Lomnitz, 1970; Lomnitz, 2004). Temporary seismological networks of the ISSA (Integrated Seismological experiment in the Southern Andes) and TIPTEQ (from The Incoming Plate to mega-Thrust EarthQuake processes) projects observed seismic events in the region during 2000 and 2004/2005, respectively (Bohm et al., 2002; Bruhn, 2003; Haberland et al., 2006). These data demonstrate that shallow earthquakes $(M \leq 5)$ are concentrating north and south of the Arauco Peninsula; they are related to a northeast-striking reverse fault adjacent to the Isla Santa María (Melnick et al., 2006) and to the northwest-striking Morguilla and Lanalhue faults, respectively.

Quaternary and recent forearc deformation on the Arauco peninsula is mostly expressed by emerged and warped coastal landforms. Several marine surfaces bear evidence of the complex interplay between local tectonic uplift and glacio-eustatic sea-level changes (e.g. Kaizuka et al., 1973; Melnick et al., 2009). The largest and best preserved surface is the Cañete terrace that developed during MIS 5e ( $125 \mathrm{ka}$ ago $)$. Two less preserved marine surfaces, named Buena Esperanza and Las Nochas, are found above the Cañete terrace and attributed to the interglacial periods of MIS 7 and MIS 9 (Kaizuka et al., 1973). The shoreline-angle elevation of these three surfaces increases towards the center of Arauco, where they reach $232 \mathrm{~m}$ (Cañete), $360 \mathrm{~m}$ (Buena Esperanza), and $471 \mathrm{~m}$ a.s.l. (Las Nochas), respectively. Uplift rates are hence highest at the center of the peninsula ( $1.8 \pm 0.2 \mathrm{~mm} / \mathrm{a})$ and lowest in its northern sector $(0.36 \pm 0.07 \mathrm{~mm} / \mathrm{a})$ (Melnick et al., 2009). The uplift rate deduced from shoreline-angle elevations of the Cañete surface adjacent to Lanalhue and Lleu Lleu lakes is $0.51 \pm 0.1 \mathrm{~mm} / \mathrm{a}$. These variations in uplift rate and shoreline-angle elevations have been attributed to a major WNW-ESE oriented anticline running along the center of the peninsula, which is ultimately responsible for its emergence. However, this fold has a complex geometry leading to a slight eastward tilt of the Cañete terrace, evident in the surroundings of the Lanalhue Lake. The fold is bounded at its northern and southern flanks by deep-seated reverse faults that are likely rooted in the plate interface, as suggested from the continuous alignment of microseismicity.

Further studies on local deformation have been conducted on two islands adjacent to the Arauco peninsula (Table 1). In their pioneer work, Kaizuka et al. (1973) studied marine terraces on the Isla Santa María, north of Arauco $\left(37^{\circ} \mathrm{S}\right)$, and correlated the uppermost surface to the Cañete terrace. Recently, Melnick et al. (2006) used radiocarbon dating of shoreline markers deriving a mean uplift of $1.8 \pm 0.4 \mathrm{~mm} / \mathrm{a}$ during the last $40 \mathrm{kyr}$, and showing that the upper surface is only $\sim 27$ ka old. Bookhagen et al. (2006) studied uplifted Holocene beach berms of the island and derived a mean uplift rate of $2.3 \pm 0.2 \mathrm{~mm} / \mathrm{a}$ over the last $\sim 3 \mathrm{ka}$. On Mocha Island, south of Arauco $\left(38.5^{\circ} \mathrm{S}\right)$, Radtke (1989) found uplift rates of $4.9 \pm 1.1 \mathrm{~mm} / \mathrm{a}$ during the last $\sim 6 \mathrm{ka}$, based on radiocarbon dating of elevated marine terraces. This is concordant with the results of Nelson and Manley (1992), who derived an uplift rate of $5.4 \pm 1.2 \mathrm{~mm} / \mathrm{a}$ for the same period of time. However, the authors provide a more complex study of strandlines on Isla Mocha in which they reveal that uplift of the island increased steadily over the past millennia (Nelson and Manley, 1992). In contrast to the Arauco peninsula and the Cañete surface, the marine terraces at Isla Mocha and Santa Maria are steeply tilted. This tilt has been related to their positions in the limbs of tight reverse-fault cored anticlines (Melnick et al., 2006). Thus, changes in uplift rates at these islands might reflect transient periods of enhanced crustal faulting and folding.

\section{Morphometry and characteristics of the Lanalhue and Lleu Lleu lakes}

A peculiarity of the south-central Chile margin is the occurrence of several coastal lagoons which are found north of the maximum extent of Patagonian glaciations precluding a glacial origin and the influence of local post-glacial isostatic rebound. They are located, for example, south of the Bío Bío river mouth $\left(\sim 37^{\circ} \mathrm{S}\right)$, in the coastal plain of southern Arauco $\left(\sim 38^{\circ} \mathrm{S}\right)$ where our study focuses on, south of the Imperial River $\left(\sim 39^{\circ} \mathrm{S}\right)$, and south of Valdivia $\left(40^{\circ} \mathrm{S}\right)$ (Endlicher and Mäckel, 1985). Today, these lagoons are mostly disconnected from the Pacific Ocean, hence forming lake basins. It has been hypothesized that the lagoons on the southern Arauco Peninsula, Lago Lanalhue and Lago Lleu Lleu (Fig. 3), developed in former river valleys at the western slope of the coastal Cordillera de Nahuelbuta (Mardones and Reuther, 1999). In their western sectors, both lakes are bordered by a coastal plain, which is composed of marine and aeolian sands as well as locally active dune belts (Mardones and Reuther, 1999). The transition area between the coastal plain and the cordillera features the late Pleistocene Cañete terrace.

The formation of Lago Lanalhue and Lago Lleu Lleu has been the matter of debate, with interpretations reaching from tectonic downwarping of the lake basins (Börgel, 1953) to an impounding of coastal rivers by eastward moving dunes (Endlicher and Mäckel, 1985). In the most recent study, Mardones and Reuther (1999) suggested a formation caused by uplifted barriers forming natural dams. 


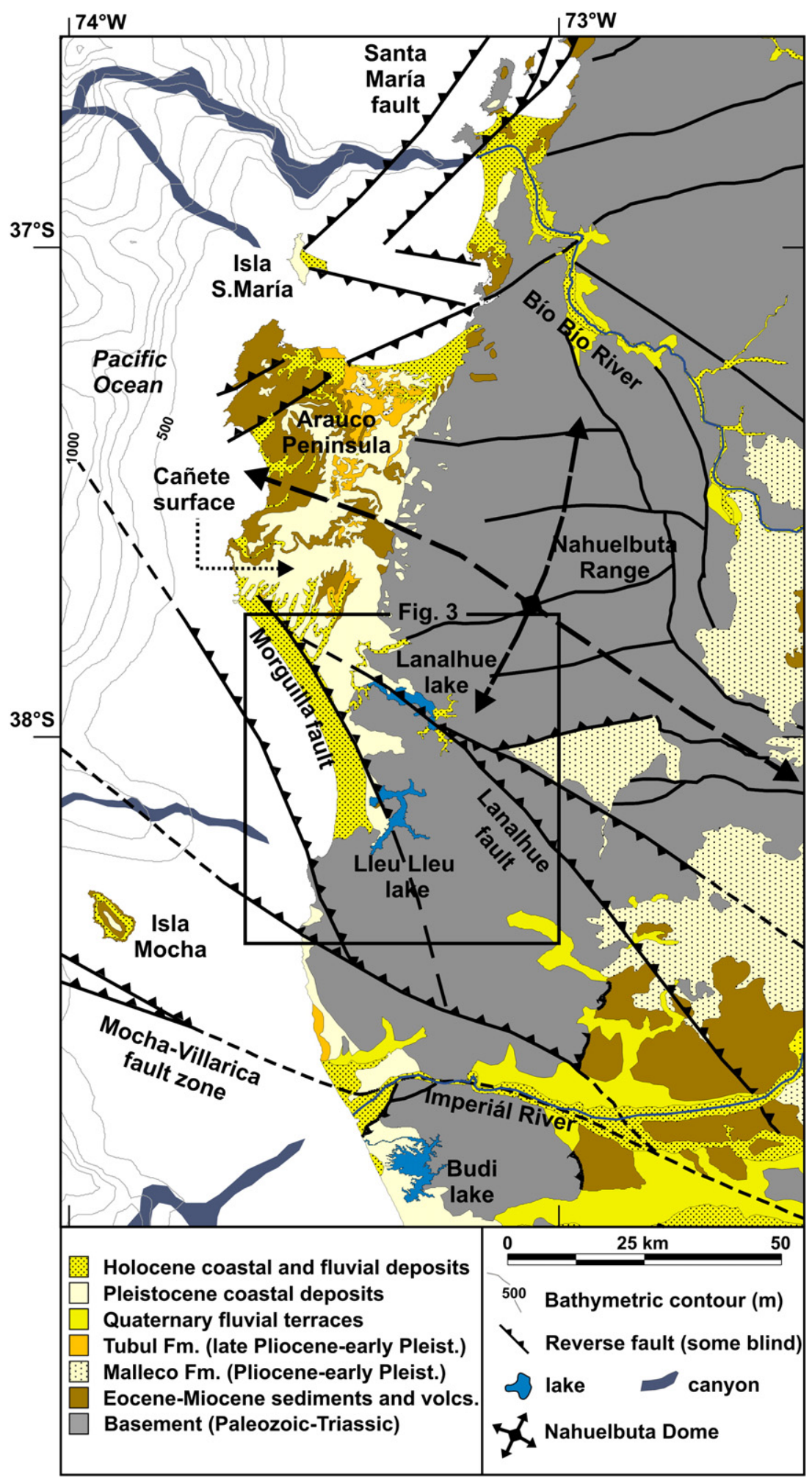

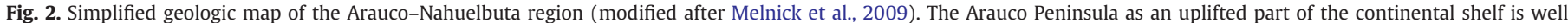
distinguishable from the Paleozoic-Triassic basement of the Nahuelbuta Range.

\subsection{Lago Lanalhue}

Lago Lanalhue is located in a SE-NW oriented, elongated depression, which can be divided into three morphologically and bathymetrically distinct segments (Fig. 4A) (Mardones and Reuther, 1999). The southern sector trends $\mathrm{N}-\mathrm{S}$, has a shallow depth of $\sim 4 \mathrm{~m}$ and subdued slopes, whereas the central part is SE-NW oriented and up to $22 \mathrm{~m}$ deep. The western T-shaped segment holds the deepest part of the lake, which is reaching a water depth of $24 \mathrm{~m}$ in the center of the former fluvial valley. In front of Lago Lanalhue, the Cañete terrace is tilted eastward about a NNW-SSE oriented axis and currently dams the catchment, thereby impounding the lake.

The present drainage area of Lago Lanalhue covers $\sim 360 \mathrm{~km}^{2}$ with a water surface area of $32.05 \mathrm{~km}^{2}$. At present, its water level is at $8.0 \pm$ $1.44 \mathrm{~m}$ a.s.l. (elevation deduced from the SRTM waterbody dataset with a mean local instrumental error of $1.44 \mathrm{~m}$ according to Becek, 2008). 
Table 1

Hitherto existing studies of uplift rates in the vicinity of the studied lakes.

\begin{tabular}{|c|c|c|c|c|c|}
\hline Location & Latitude & Time-period & Uplift (mm/a) & Study based on & Author(s) \\
\hline \multirow[t]{2}{*}{ Sta. María Island } & $37^{\circ} \mathrm{S}$ & Last 40,000 years & $1.8 \pm 0.4$ & Paleosols, peat, clay layers $\left({ }^{14} \mathrm{C}\right.$ AMS dating) & Melnick et al. (2006) \\
\hline & & Last 3000 years & 2.3 & Elevated strandlines (OSL dating) & Bookhagen et al. (2006) \\
\hline \multirow[t]{2}{*}{ Arauco Peninsula } & $37-38.5^{\circ} \mathrm{S}$ & Last 125,000 years & $0.8-2.0$ & Eemian terrace (geomorphic observation) & Kaizuka et al. (1973) \\
\hline & & Last 125,000 years & $\max .1 .8 \pm 0.2 \min .0 .36 \pm 0.07$ & Eemian terrace (dated cosmogenic nuclides) & Melnick et al. (2009) \\
\hline \multirow[t]{2}{*}{ Mocha Island } & $38^{\circ} \mathrm{S}$ & Last 6000 years & $4.9 \pm 1.1$ & Terraces (dated shell fragments) & Radtke (1989) \\
\hline & & Last 6000 years & $5.4 \pm 1.2^{*}$ & Strandlines (radiocarbon dated shells) & Nelson and Manley (1992) \\
\hline
\end{tabular}

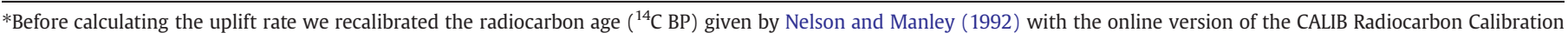
program (Execute Version 5.0.2html; Stuiver et al. (2005)).

Several small streams running down the western slope of the Cordillera de Nahuelbuta are discharging into the lake. The outlet of Lago Lanalhue-a small stream named Río Paicaví-is located at the western end of the lake, from where it flows out to the Pacific Ocean through an oversized fluvial valley incised in the Cañete surface (Fig. 3). Along the course of the stream, the entire sequence of the Cañete deposits has been incised and the Río Paicaví is currently flowing on the local metamorphic bedrock.

\subsection{Lago Lleu Lleu}

Lago Lleu Lleu is located $\sim 15 \mathrm{~km}$ south of Lago Lanalhue and has a characteristic branched shape (Fig. 4B). Its main water body extends about $17 \mathrm{~km}$ in NNE-SSW direction as well as $0.5-3 \mathrm{~km}$ in W-E direction. The frontal (northwestern) part of the lake is very shallow with a depth of $\sim 10 \mathrm{~m}$, whereas water depth reaches more than $40 \mathrm{~m}$ in the central and deepest part.

The present drainage area of the lake amounts to $\sim 580 \mathrm{~km}^{2}$ with an area of the water surface of $37 \mathrm{~km}^{2}$. The present water level of Lago Lleu Lleu is situated at $5.0 \pm 1.44 \mathrm{~m}$ a.s.l. Small tributaries are draining into the lake mainly from the Cordillera de Nahuelbuta in the east. The small outlet that drains the lake to the Pacific Ocean-Río Lleu Lleu-is located in the outmost northwest and is only $\sim 6.3 \mathrm{~km}$ long (Fig. 3).

\section{Material and methods}

\subsection{Seismic survey}

Reflection seismic surveys were executed on Lago Lleu Lleu in January 2002 and on Lago Lanalhue in November 2005 with a highresolution CENTIPEDE sparker and a very-high-resolution GEOPULSE subbottom profiler ('pinger'). The small scientific vessel "Huala II" from the Universidad Austral de Chile towed the CENTIPEDE multielectrode sparker (300 J, main frequency: 400-1500 Hz) as seismic source and a single-channel high-resolution streamer as receiver. For a more detailed image of the subsurface, we used the "pinger" source/ receiver $(3.5 \mathrm{kHz})$, which was mounted on a Cataraft system. Navigation and positioning was done by GPS (Global Positioning System). All data were recorded digitally on a TRITON-ELICS Delph-2 acquisition system. Seismic stratigraphic interpretation was done using SMT's Kingdom

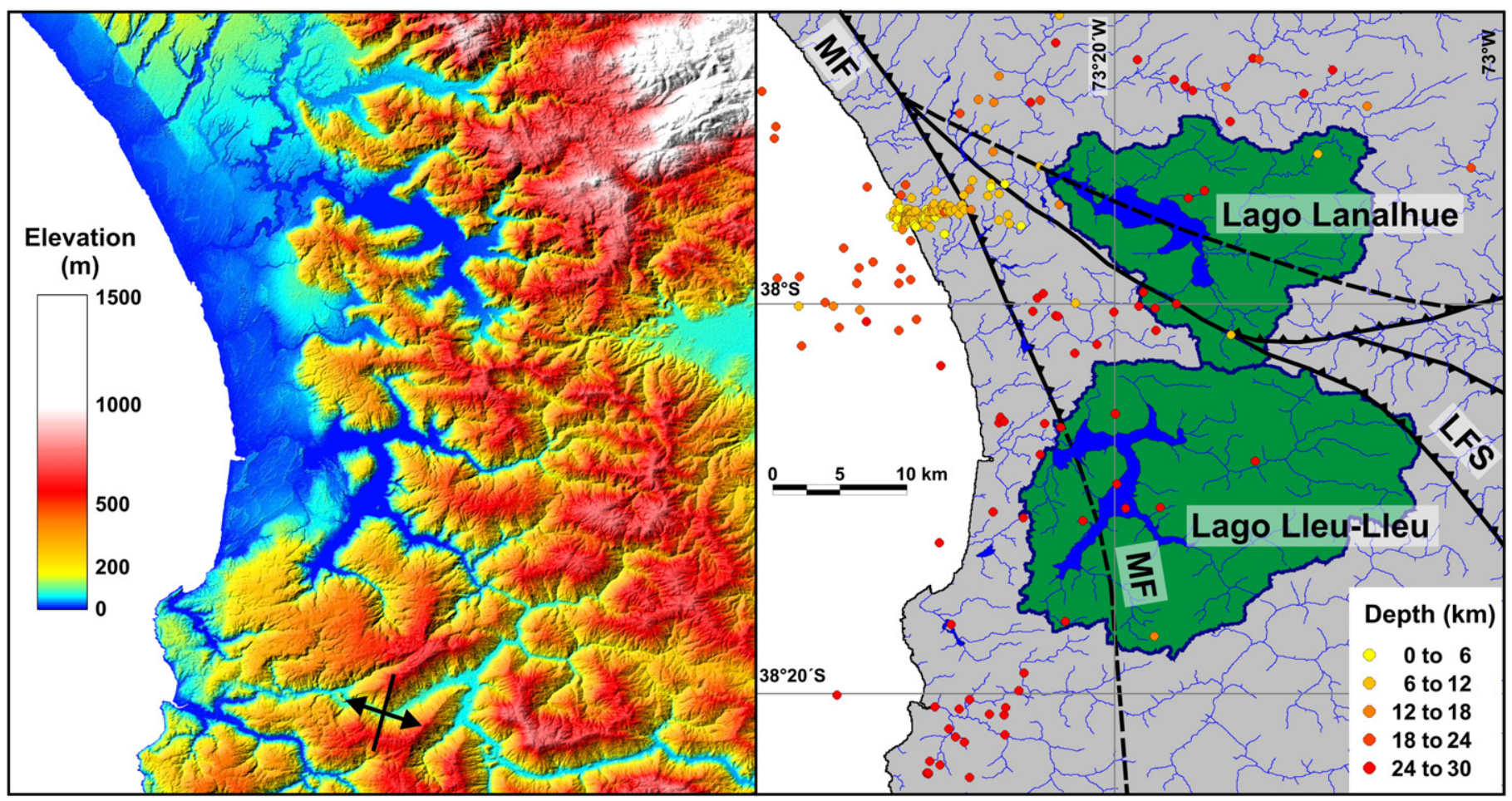

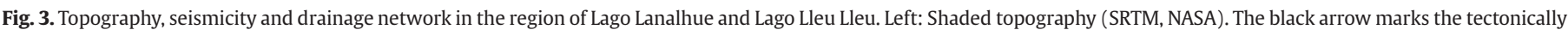

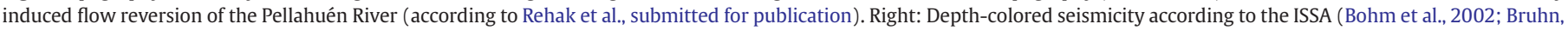

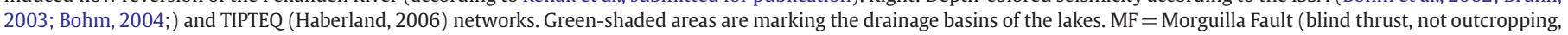
northern part after Melnick et al., 2009), LFS = Lanalhue Fault System (Glodny et al., 2008a). 
Suite package. Water and subsurface depths were calculated using a mean acoustic velocity of $1500 \mathrm{~m} / \mathrm{s}$. Acoustic penetration in the deeper parts of Lago Lanalhue was rather limited due to gas blanking.

\subsection{Coring and core processing}

Several sediment cores of $6.6 \mathrm{~cm}$ inner diameter were retrieved from both lakes in November/December 2005, using a gravity corer as well as a 5-m-long piston-corer system from an anchored raft. With the piston-corer, two or three overlapping core pieces were taken at one and the same position, assuring a complete recovery of up to $\sim 13 \mathrm{~m}$. All coring positions were defined on the basis of seismicreflection profiles before drilling; navigation and positioning was again done by GPS. Due to strong winds and lake currents, positioning and anchoring of the raft hit the defined locations within a tolerance of $\pm 30 \mathrm{~m}$. A summary of the retrieved cores and an overview of their locations are given in Table 2 and Fig. 4.

All cores were opened, photographed and lithologically described concerning their colour, grain size, structures and the occurrence of microfossils. Subsequently, magnetic susceptibility was measured with a BARTINGTON MS2E sensor in 1-mm-steps. The overlapping $5 \mathrm{~m}$-long sections at each coring position were combined, using the magnetic susceptibility results and the detailed core description. Using this method a composite depth was developed for every single core. For each lake, the core with the best and longest recovery was defined as the respective 'master core', on which the further measurements, e.g. radiocarbon dating, were carried out. The Lago Lanalhue master core has a composite depth of 13.25 mcd (meter composite depth); it is constructed by using part of the corresponding gravity core LA-SL012 for the uppermost meter and the piston core LA-KL013 (1.0$13.25 \mathrm{mcd}$ ) below. The master core of Lago Lleu Lleu is $12.22 \mathrm{mcd}$ long; it is composed of gravity core LL-SL008 in the topmost $0.55 \mathrm{mcd}$ and the corresponding piston core LL-KL009 below (0.55-12.22 mcd). For simplification, we refer to them as LA-KL013 and LL-KL009 for the composited sequences in the following.

\subsection{Radiocarbon dating}

The chronology for both lakes is based on radiocarbon dating of their respective master cores. The radiocarbon measurements were done at the Leibniz Laboratory in Kiel and at the ETH (Swiss Federal Institute of Technology) Zurich. If procurable, dating was done on plant fragments, bivalve shells or foraminifera. The latter were sampled using wet-sieving (mesh-width $125 \mu \mathrm{m}$ ) and identified as well as hand-picked under a binocular microscope. In those parts of the cores that were lacking datable material, we used bulk sediments. Absolute age control is provided by 13 AMS radiocarbon dates for Lago Lanalhue. Eight datings were done on material of the piston-core LAKL013 (Table 3a); the remaining dates were measured on material of gravity cores LL-SL010 + SL012 and correlated by means of magnetic susceptibility. Age control for the Lleu Lleu sequence is provided by ten AMS radiocarbon dates of which nine were done on piston-core LL-KL009 (Table 3b). One age was determined on material of gravity core LL-SL008 and correlated by magnetic susceptibility as well.

To calibrate the radiocarbon ages to calendar years we used the online version of the CALIB Radiocarbon Calibration (Execute Version 5.0.2html) of Stuiver et al. (2005) with the Southern Hemisphere Calibration curve (SHCal04) of McCormac et al. (2004) and the marine calibration curve (marine04) of Hughen et al. (2004a) for the lowermost marine sections of both cores. All ages are reported in years BP (before present). For those datings done on marine samples, a regional deviation of the global reservoir effect $(\Delta R=61 \pm 50$ years) was considered according to the embedded Marine Reservoir Correction Database (http://intcal.qub.ac.uk/marine/). To generate point estimates, we calculated the weighted average of the obtained $2 \sigma$ ranges, using the range mid-points (cf. e.g. Telford et al., 2004). For the subsequent

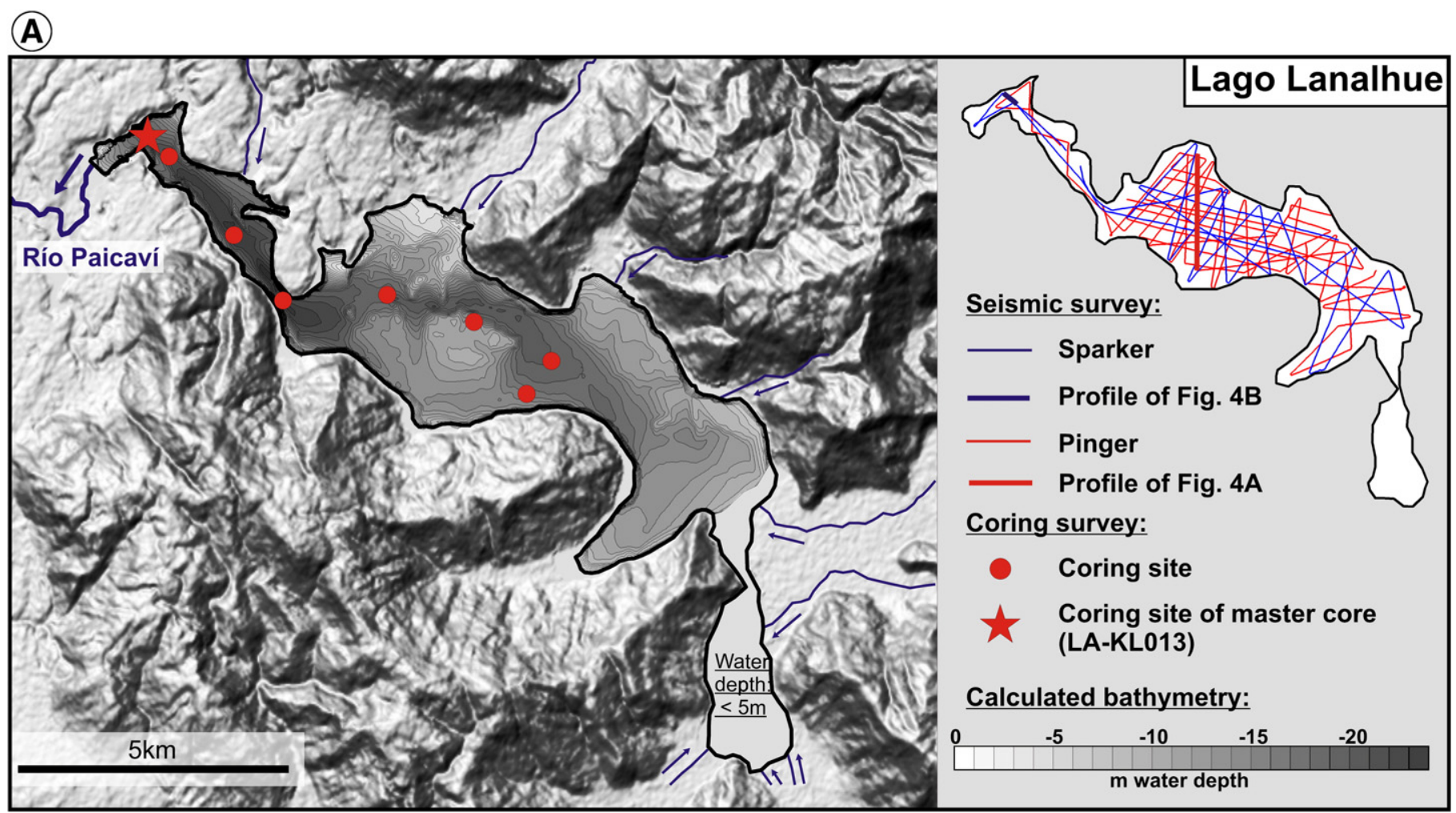

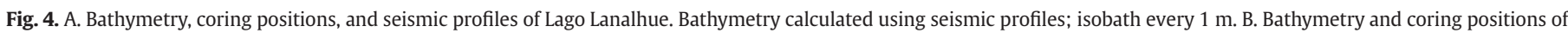
Lago Lleu Lleu. Bathymetry derived from Urrutia et al. (2000); isobath every $10 \mathrm{~m}$. 
(B)

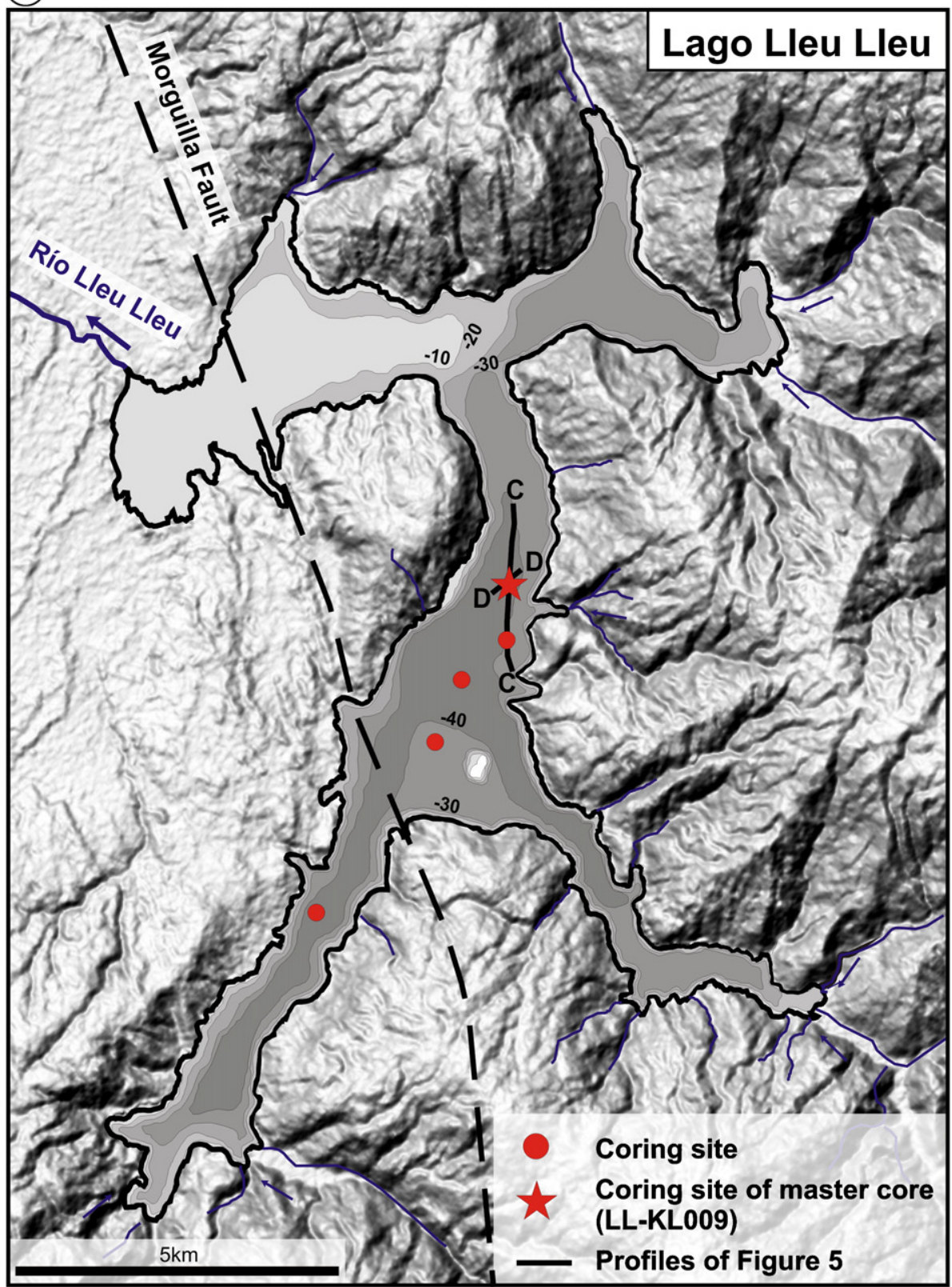

Fig. 4 (continued).

construction of the age models we used linear interpolation between these point data, as well as linear extrapolation to the cores top and base.

\section{Results}

\subsection{Seismic interpretation}

Seismic stratigraphic analyses reveal a major unconformity in the sedimentary infill of both basins. It forms an irregular morphology with pre-lake incisions up to $20 \mathrm{~m}$ and $30 \mathrm{~m}$ deep in the underlying basement of Lago Lanalhue and Lago Lleu Lleu, respectively; slope angles of the incision reach values of more than $20^{\circ}$ (Fig. 5). These erosional features developed into thick pre-Holocene sedimentary sequences. The dense survey spacing in Lago Lanalhue allowed the detailed mapping of the major unconformity, which has the morphology of a main valley and several smaller lateral gullies. Some of these channels and the overall morphology of the former fluvial drainage system are still visible in the bathymetric map (Fig. 4A). The incisions originate at the main tributaries discharging into the lake and generally deepen in westward direction, emphasizing pre-lake fluviatile morphology.

Seismic reflection profiles also indicate a major stratigraphic boundary in the lake filling sediments, which is clearly pronounced in Lago Lleu Lleu but less distinct in Lago Lanalhue (Fig. 5). On pinger sections from Lago Lleu Lleu this transition is marked by the lower limit of the clear acoustic penetration, while sparker sections of both lakes indicate a subtle change in depositional conditions. The apparent transition delimits a lower sedimentary unit (Facies 1, see Fig. 5), which is restricted to the topographic lows of the ancient fluvial drainage system, and an upper sedimentary unit (Facies 2) that fills these former depressions but also drapes the shallower areas (being condensed in those parts). Generally no sedimentation occurred in regions of the lake where water 
Table 2

List of gravity and piston cores from Lago Lanalhue (LA) and Lago Lleu Lleu (LL).

\begin{tabular}{lllll}
\hline Core name & Core type & $\begin{array}{l}\text { Original } \\
\text { core length } \\
\end{array}$ & & \multicolumn{2}{l}{$\begin{array}{l}\text { Site position } \\
\text { (UTM coordinates) }\end{array}$} \\
\cline { 4 - 5 } & & & Easting (18H) & Northing \\
\hline LA-SL001 & Gravity core & 172 & 646857 & 5802276 \\
LA-SL002 & Gravity core & 42 & 648275 & 5801860 \\
LA-SL003 & Gravity core & 172 & 649571 & 5801279 \\
LA-SL004 & Gravity core & 168 & 649206 & 5800683 \\
LA-KL005 & Piston core & 895 & 649206 & 5800683 \\
LA-KL006-008 & Piston core & $232-1280$ & 646857 & 5802276 \\
LA-KL009 & Gravity core & 222 & 644990 & 5802300 \\
LA-KL010 & Gravity core & 205 & 644206 & 5803390 \\
LA-KL011 & Gravity core & 188 & 642984 & 5804850 \\
LA-SL012 & Gravity core & 185 & 642668 & 5805180 \\
LA-KL013-014 & Piston core & $1248-1308$ & 642668 & 5805180 \\
LL-SL001 & Gravity core & 106 & 644421 & 5771320 \\
LL-SL002 & Gravity core & 124 & 646234 & 5773892 \\
LL-SL003 & Gravity core & 147 & 646648 & 5774903 \\
LL-SL004 & Gravity core & 132 & 647301 & 5775339 \\
LL-KL005-006 & Piston core & $893-942$ & 646648 & 5774903 \\
LL-KL007 & Piston core & 454 & 646234 & 5773892 \\
LL-SL008 & Gravity core & 129 & 647347 & 5776185 \\
LL-KL009 & Piston core & 1260 & 647347 & 5776185 \\
\hline
\end{tabular}

depth is less than $14 \mathrm{~m}$. This sediment focussing process generally smoothes the irregular lake bottom morphology, but still the contours of the former fluvial valleys are clearly visible in the present-day bathymetry. Core-to-seismic correlation further suggests that drilling operations reached the former river bed in Lago Lanalhue, although no fluvial material could be recovered (probably due to its higher resistance and coarser grain size), whereas in Lago Lleu Lleu coring stopped some decimeters above this discontinuity (Fig. 5).

\subsection{Sediment lithology}

Similarly to the seismic analyses, two main stratigraphic units have been identified from the lithological description of the cores (Facies 1 and Facies 2), both in Lago Lanalhue and Lago Lleu Lleu (Fig. 6A-B).

\subsubsection{Lago Lanalhue}

The lowermost facies of the Lanalhue sediments (Facies 1a, 13.25$12.44 \mathrm{mcd}$ ) unconformably overlies the ancient riverbed, as revealed by seismic data. It consists of dark-grey clayey sand with sporadically embedded, non-destructed bivalve shells (Mulinia edulis King and Broderip, 1832) and foraminifera of the benthic species Ammonia tepida (Cushman, 1926). Magnetic susceptibility is higher-than-average for this part of the section, reaching values around $6000 \times 10^{-6}$ (Fig. 6A). Upwards, the clayey sand grades to homogeneous silty clay (Facies 1b, $12.44-12.09 \mathrm{mcd})$ that still contains benthic foraminifera but has lower values of magnetic susceptibility $\left(\sim 2000 \times 10^{-6}\right)$.

Table 3a

AMS ${ }^{14} \mathrm{C}$ ages of the Lanalhue master core (LA-KL013).

\begin{tabular}{llrrlll}
\hline $\begin{array}{l}\text { Orig. } \\
\text { depth } \\
(\mathrm{m})\end{array}$ & $\begin{array}{l}\text { Core nr. } \\
\text { (LA-) }\end{array}$ & $\begin{array}{l}\text { Comp. } \\
\text { depth } \\
\text { (mcd) }\end{array}$ & $\begin{array}{l}{ }^{14} \text { C AMS } \\
\text { age (years) }\end{array}$ & $\begin{array}{l}\text { Calibrated age } \\
\text { (yr cal. B.P.) }\end{array}$ & $\begin{array}{l}\text { Laboratory } \\
\text { number }\end{array}$ & Dated material \\
\hline 0.63 & SL012 & 0.63 & $210 \pm 25$ & 198 & KIA31962 & Plant fragments \\
0.67 & SL010 & 0.70 & $215 \pm 25$ & 204 & KIA31957 & Degr. leaves \\
1.33 & SL010 & 1.42 & $1040 \pm 30$ & 888 & KIA31960 & Plant fragments \\
1.83 & SL012 & 2.17 & $1750 \pm 30$ & 1606 & KIA31963 & Degr. leaves \\
2.59 & KL013 & 2.88 & $3915 \pm 25$ & 4297 & KIA31964 & Bulk sediments \\
4.60 & KL013 & 4.76 & $3555 \pm 30$ & 3779 & KIA29621 & Plant leaf \\
5.80 & KL013 & 5.96 & $3855 \pm 31$ & 4192 & KIA31965 & Plant fragments \\
7.27 & KL013 & 7.43 & $4175 \pm 30$ & 4751 & KIA29622 & Wood fragments \\
8.71 & KL013 & 8.85 & $5860 \pm 35$ & 6593 & KIA29642 & Shell fragments \\
9.39 & KL013 & 9.53 & $6150 \pm 35$ & 6972 & KIA31966 & Bulk sediments \\
10.68 & KL013 & 10.82 & $7240 \pm 35$ & 7662 & KIA29623 & Bivalve shell \\
12.19 & KL013 & 12.33 & $7280 \pm 35$ & 8053 & KIA29624 & Wood fragments \\
12.29 & KL013 & 12.43 & $7790 \pm 40$ & 8186 & KIA29625 & Bivalve shell \\
\hline & & & & & & \\
\hline
\end{tabular}

Table 3b

AMS ${ }^{14} \mathrm{C}$ ages of the Lleu Lleu master core (LL-KL009).

\begin{tabular}{|c|c|c|c|c|c|c|}
\hline $\begin{array}{l}\text { Orig. } \\
\text { depth } \\
\text { (m) }\end{array}$ & $\begin{array}{l}\text { Core nr. } \\
\text { (LL-) }\end{array}$ & $\begin{array}{l}\text { Comp. } \\
\text { depth } \\
\text { (mcd) }\end{array}$ & $\begin{array}{l}{ }^{14} \mathrm{C} \text { AMS } \\
\text { age (years) }\end{array}$ & $\begin{array}{l}\text { Calibrated age } \\
\text { (yr cal. B.P.) }\end{array}$ & $\begin{array}{l}\text { Laboratory } \\
\text { number }\end{array}$ & Dated material \\
\hline 0.09 & KL009 & 0.07 & $550 \pm 45$ & 533 & ETH-35361 & $\begin{array}{l}\text { Degr. leaves, } \\
\text { wood }\end{array}$ \\
\hline 0.20 & SL008 & 0.20 & $770 \pm 25$ & 681 & KIA31982 & Plant leave \\
\hline 107.5 & KL009 & 1.02 & $2325 \pm 45$ & 2256 & ETH-35362 & $\begin{array}{l}\text { Degr. leaves, } \\
\text { wood }\end{array}$ \\
\hline 1.29 & KL009 & 1.23 & $2635 \pm 45$ & 2656 & ЕTH-35363 & $\begin{array}{l}\text { Degr. leaves, } \\
\text { wood }\end{array}$ \\
\hline 2.57 & KL009 & 2.51 & $5210 \pm 55$ & 5883 & ETH-35364 & $\begin{array}{l}\text { Degr. leaves, } \\
\text { wood }\end{array}$ \\
\hline 4.30 & KL009 & 3.93 & $7675 \pm 40$ & 8076 & KIA29626 & Shell fragments \\
\hline 4.68 & KL009 & 4.31 & $8075 \pm 45$ & 8481 & KIA29627 & Shell fragments \\
\hline 9.10 & KL009 & 8.73 & $9310 \pm 50$ & 10033 & KIA31979 & Ammonia tepida \\
\hline $11.65^{*}$ & KL009 & 11.28 & $9230 \pm 55$ & 10366 & KIA31980 & Degr. leaves \\
\hline $12.40^{*}$ & KL009 & 12.03 & $10170 \pm 55$ & 11056 & KIA31981 & Ammonia tepida \\
\hline
\end{tabular}

*Samples calibrated with CALPAL software (online version); for the lowermost sample we considered a marine reservoir age of 400 years (see text).

Facies 2 of the Lanalhue sequence is lying on top of Facies 1 and composed of organic-rich silty clay. Calcareous microfossils are completely absent. The mean values of magnetic susceptibility are $1000 \times 10^{-6}$, just a fractional amount of the values that were measured for Facies 1 . Large parts of Facies 2 appear to be very homogenous and just slightly laminated (Facies 2a, 12.09-10.80 mcd and 5.81-0 mcd); a smaller part is, however, characterized by a regular occurrence of diatom-rich layers (Facies 2b, 10.80-5.81 mcd).

\subsubsection{Lago Lleu Lleu}

The lowermost facies of the Lleu Lleu sediments (Facies 1 ) is composed of homogenous silty clay and also contains foraminifera of the benthic species Ammonia tepida (Cushmann, 1926); non-destructed marine bivalves (Thyasira cf. magellanica Dall 1901 Tindaria striata King and Broderip, 1832) are sporadically occurring. Magnetic susceptibility values average $\sim 500 \times 10^{-6}$ (Fig. 6B) and are hence distinctly lower than those of the analogue facies in Lago Lanalhue. With a thickness of nearly $8 \mathrm{~m}$ (12.22-4.01 mcd) Facies 1 of Lago Lleu Lleu is also fivefold thicker than its counterpart at Lago Lanalhue.

Facies 2 of the Lleu Lleu sequence is situated above Facies 1 and consists of dark laminated, organic-rich, silty clay devoid of foraminifera. In its lowermost part (Facies 2a, 4.01-2.12 mcd), the sediments are very homogeneous, but, nevertheless, show a sudden increase of magnetic susceptibility values from $\sim 250 \times 10^{-6}$ to $\sim 1000 \times 10^{-6}$ (Fig. 6B). In its upper part, Facies 2 is characterized by frequent interbedded layers of homogenous clay, organic matter and mica (Facies $2 \mathrm{~b}, 2.12-0 \mathrm{mcd}$ ). Magnetic susceptibility values remain high $\left(\sim 1000 \times 10^{-6}\right)$.

\subsection{Stratigraphy and timing of the transition between the main facies}

According to the radiocarbon dating and the developed age model, the base of the Lanalhue master core (LA-KL013) has an age of $~ 9200$ calibrated years (cal yr) BP (Fig. 6A). Age control is provided by 13 dating points, which are, except for one outlier, in stratigraphic order. The non-fitting age, however, was measured on bulk sediments and may have been contaminated by reworked material. As a matter of course, the erroneous age was neglected for the age model. The master core of Lago Lleu Lleu (LL-KL009) has a basal age of $~ 11,250$ calibrated years BP. Age control of the Lleu Lleu sequence is provided by ten dating points in stratigraphic order (Fig. 6B).

Based on the developed age models, we calculated the timing of transition between the two main facies for each of the lakes. We defined the transition point of the respective core as the point at 

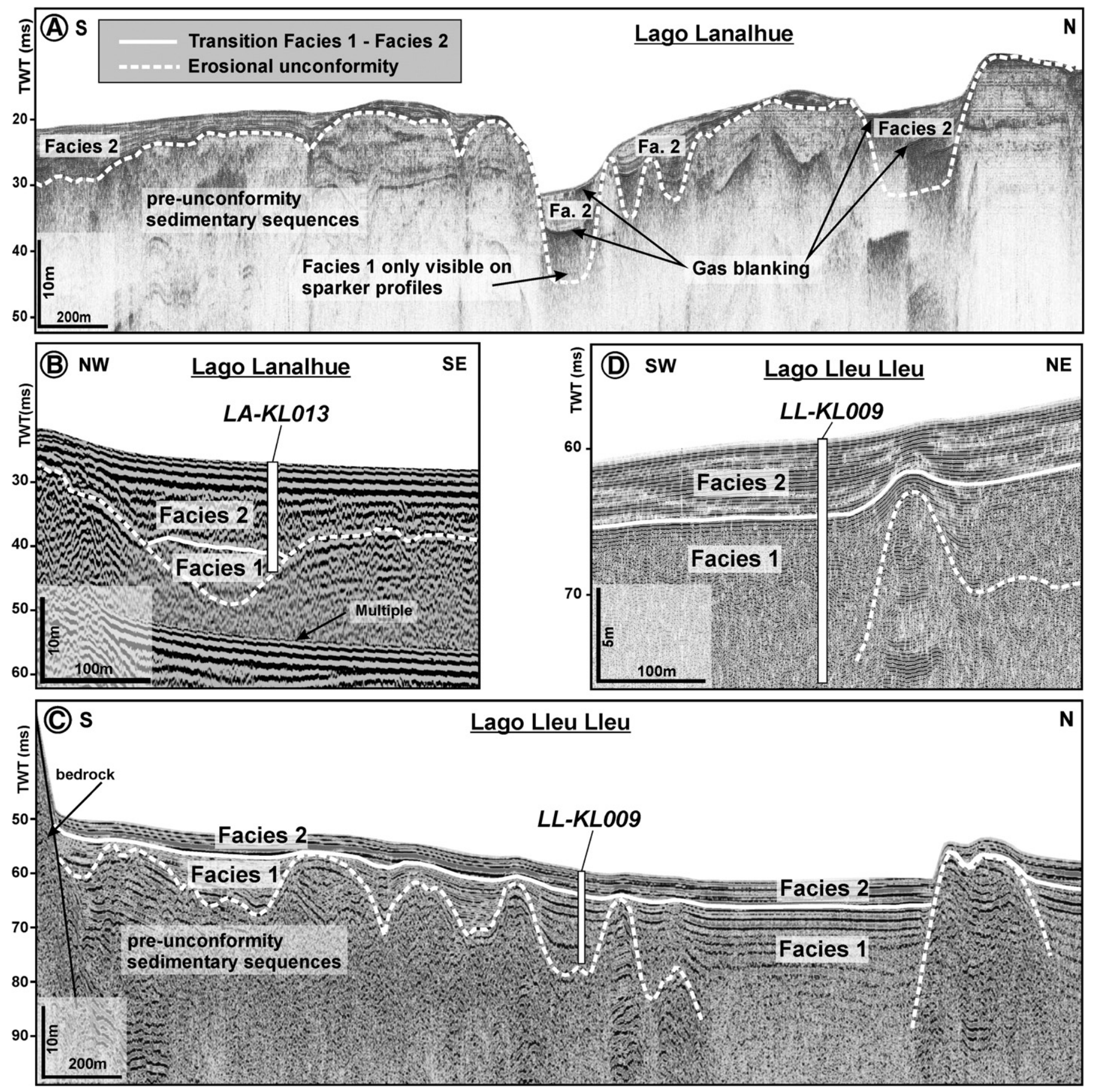

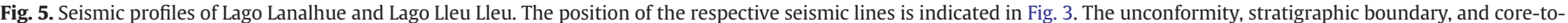

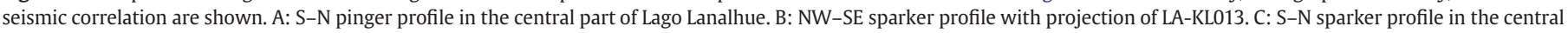
part of Lago Lleu Lleu with projection of LL-KL009. D: Pinger profile with projection of LL-KL009.

which foraminifera start to be absent. According to this approach, the transition took place first in Lago Lleu Lleu, at approximately $8150 \mathrm{cal}$ yr BP, and then in Lago Lanalhue, at about 8000 cal yr BP (Fig. 6A-B).

\section{Discussion}

Sedimentary records are regularly used for the reconstruction of past natural environments since their depositional processes are highly susceptible to changes in the environmental conditions. Accordingly, in terms of tectonics in active regions like south-central Chile, sedimentary sequences may provide insight into local deformation processes (e.g. Encinas et al., 2006), recurrent seismicity (e.g. Moernaut et al., 2007;
Bertrand et al., 2008; Blumberg et al., 2008), and secondary implications (e.g. tsunamis, Cisternas et al., 2005). In this study, we focus on the first mentioned aspect and evaluate the sediments of Lago Lanalhue and Lago Lleu Lleu concerning their potential of recording local forearc deformation. The most relevant observations obtained from our seismic and sedimentary analyses of both lakes, are 1) the existence of ancient fluvial drainage systems where the lakes developed and that predetermined the shape and depth of the present-day lakes, and 2) the occurrence of a marked marine-to-lacustrine transitional layer in the lake sediments, which enabled us to calculate the attendant local uplift rates. Based on those major findings, we interpret the different stages of the lakes development and the lake-forming deformation processes. 

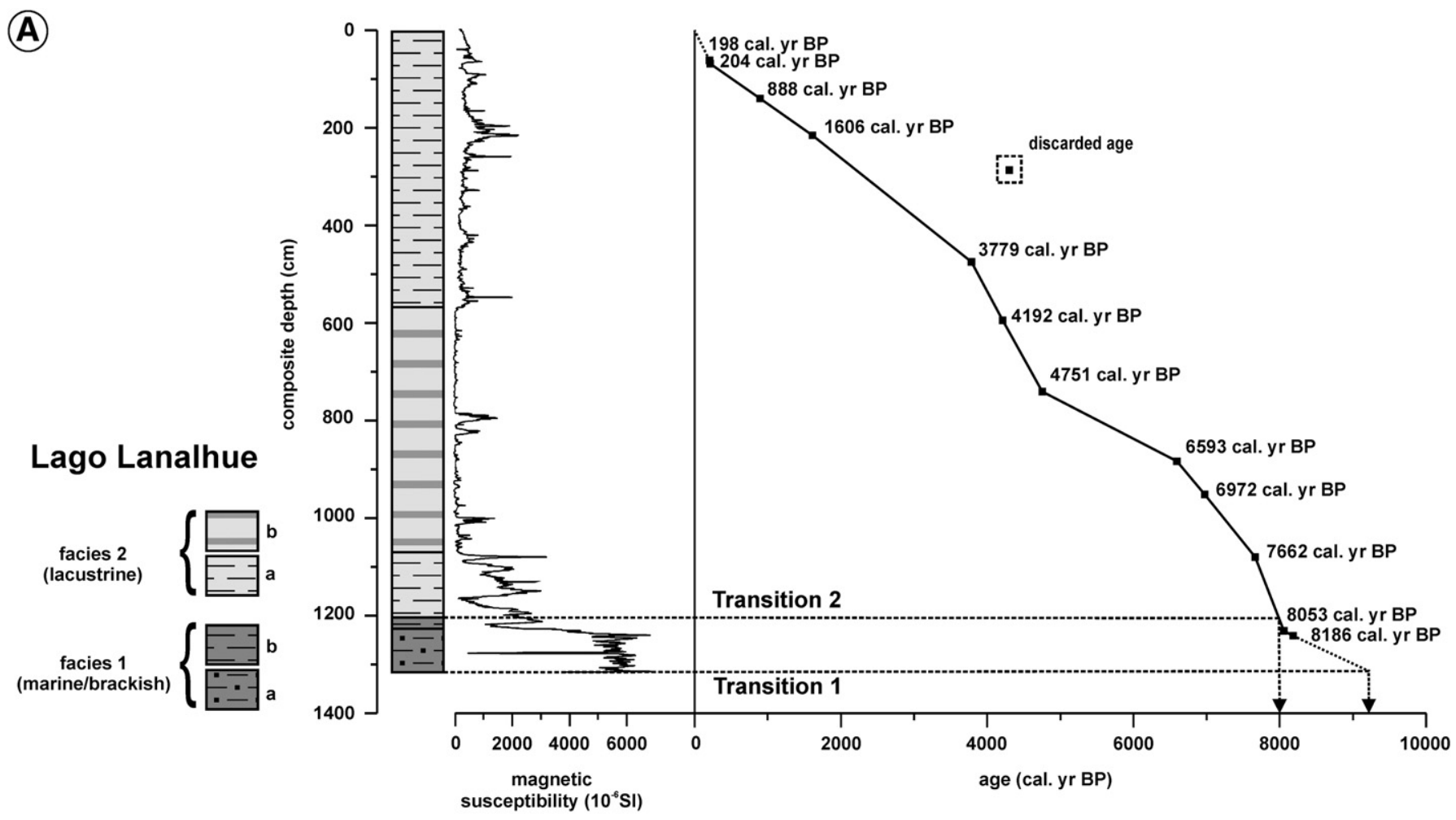

(B)
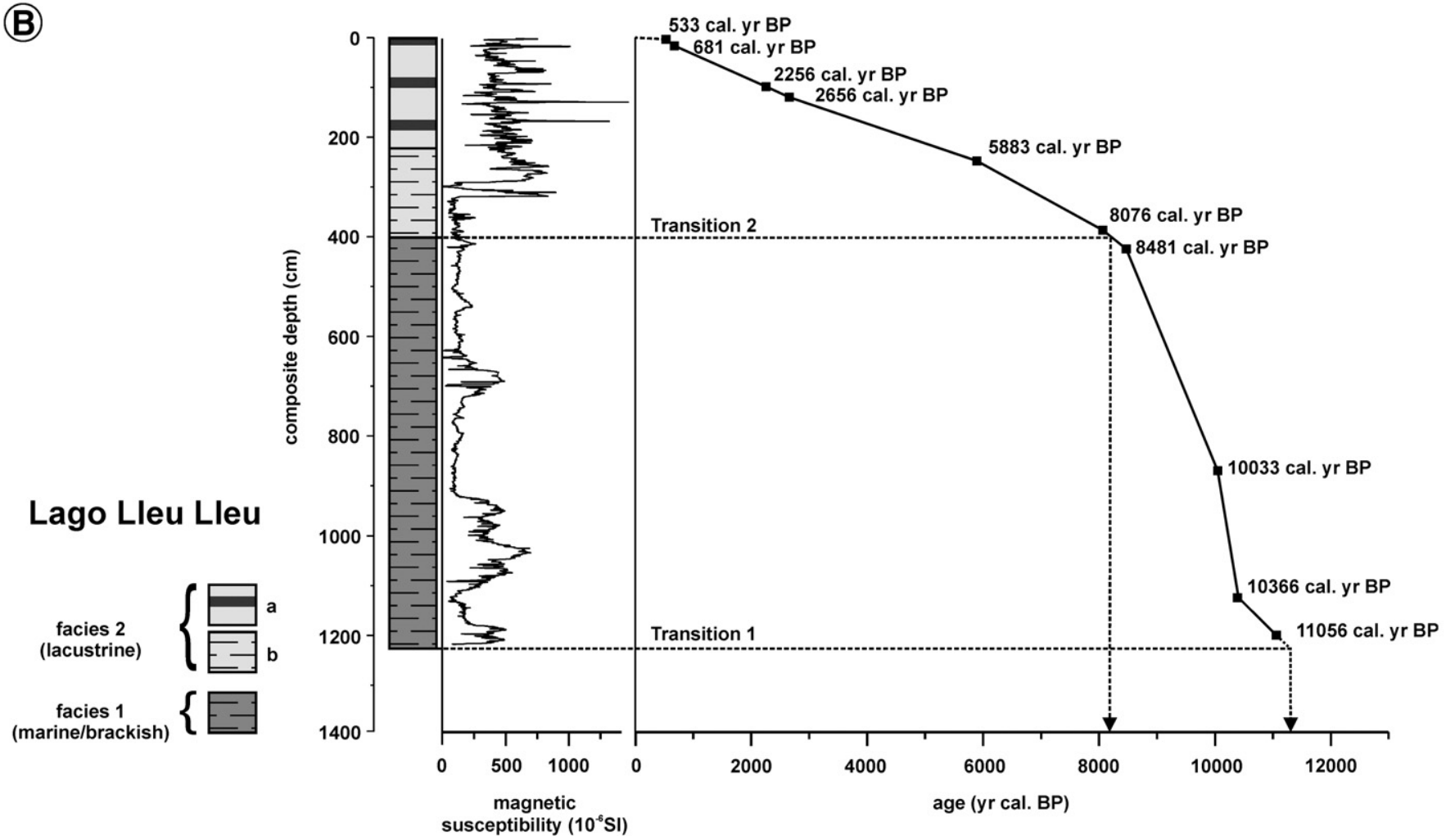

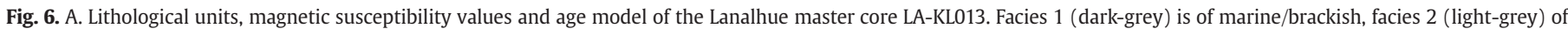

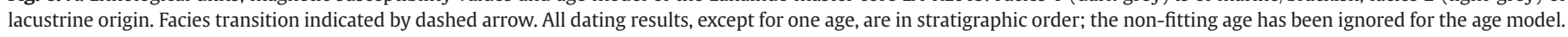

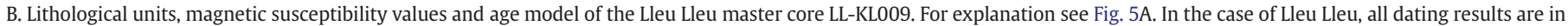
constant stratigraphic order.

\subsection{Geomorphic and stratigraphic evolution of the lakes}

In the most recent study about Lago Lanalhue and Lago Lleu Lleu, Mardones and Reuther (1999) speculated that the lakes developed in estuary systems of pre-existing river valleys that were once connected with the Pacific Ocean. The formation time of the ancient valleys is not known, but it is most likely that they were at least deepened during the last glaciation when the sea level was $\sim 120$ m lower, leading to an 
inferior local base level and probably to a higher stream power, which thus likely enhanced erosion rates. It has been previously suggested that the lakes are separated from the ocean by uplifted barriers forming natural dams and impounding the water bodies behind them (Mardones and Reuther, 1999); as shown in the following, our data support this hypothesis. However, the time at which the fluvial system was blocked and the lakes fully developed has remained unclear so far. By analyzing the sedimentary sequences deposited on top of the former river beds, we are able to reconstruct the lakes history circumstantially (cf. Fig. 7).

Sediment deposition above the former river valley started at 9200 cal yr BP in Lanalhue and 11,250 cal yr BP in Lleu Lleu. Since drilling operations stopped little above the ancient valley floor in Lago Lleu Lleu, it is important to regard the given age as a minimal value. In both lakes, the sedimentary unit directly above the former river bed is containing marine bivalves and foraminifera of the benthic species Ammonia tepida (Cushmann, 1926). As the genus Ammonia (Bruenich, 1772 ) generally typifies a marginal marine, saline to brackish environ- ment (e.g. Murray, 1991), its occurrence clearly manifests the development of lagoon-like conditions. Furthermore, a restricted abundance of microfossil species is another argument in favor of a restricted environment (brackish in this case). We hence interpret that the former river valleys were flooded-at least marginally-by the marine transgression at the end of the last deglaciation/beginning of the Holocene (Fig. 7A). The temporal mismatch of $\sim 2000$ years between the marine flooding of the two river valleys is most likely due to differences in their height above sea level at the respective times, originating from the very different morphometric and geologic (e.g. bedrock erodibility) character of the river catchments. Moreover, the differences in thickness and characteristic of the marine parts in Lago Lanalhue ( $>1$ m thick, mainly sandy material) and Lago Lleu Lleu (nearly $8 \mathrm{~m}$ thick, clayey material; cp. paragraph 5.2) are in all likelihood a consequence of different depositional conditions during the time when both systems were in connection with the Pacific Ocean.

In contrast to the marine facies, the upper sedimentary facies is completely devoid of any foraminifera in both of the lakes. The

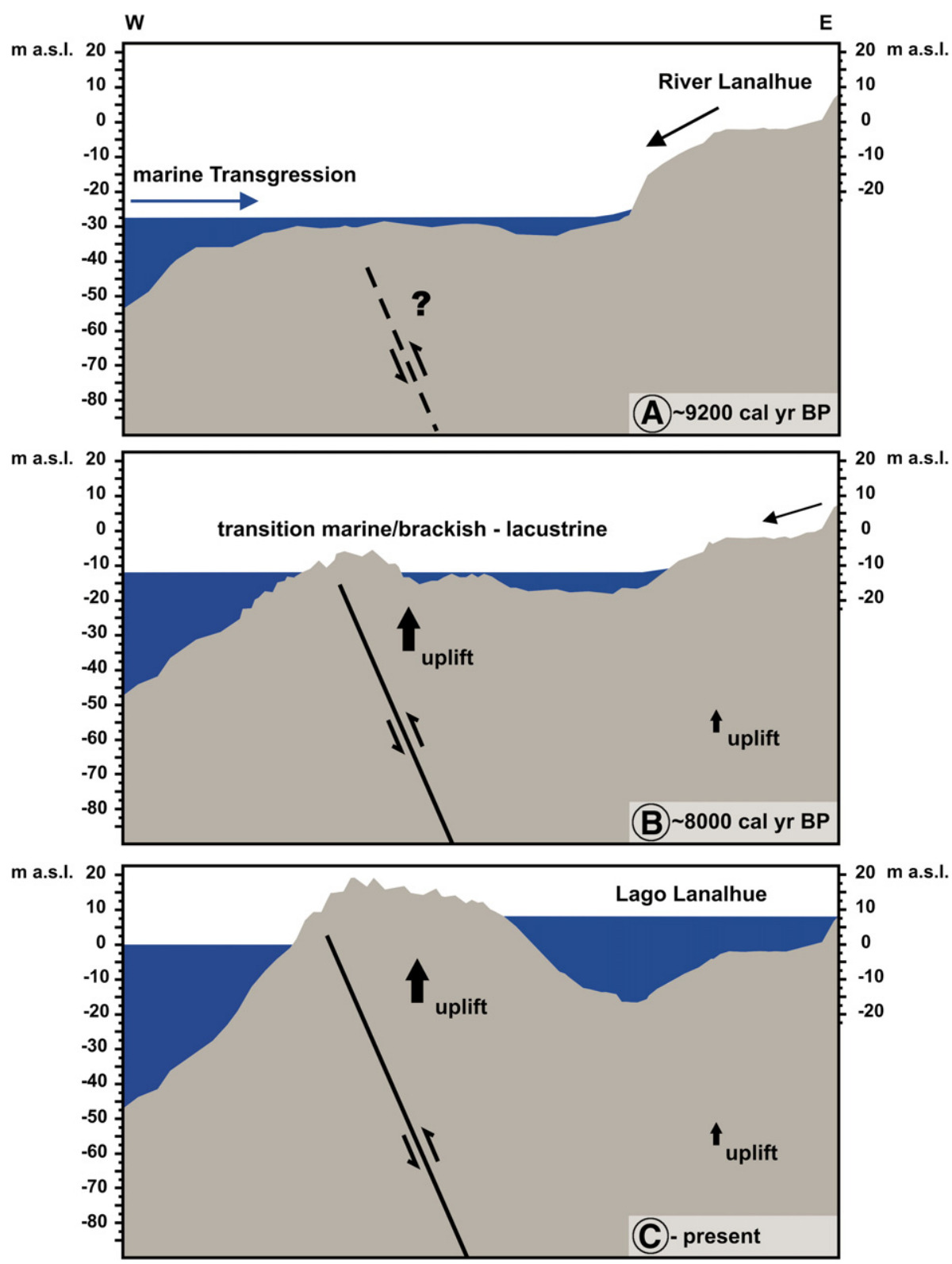

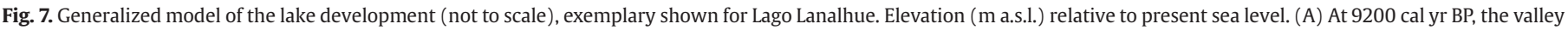

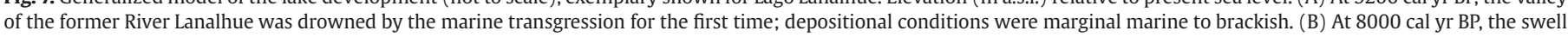

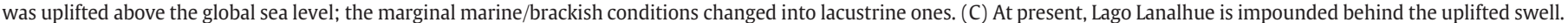


absence of foraminifera indicates the transition from the lagoonallike to a lacustrine environment, and hence points to the ultimate separation of the lakes from the Pacific Ocean. We therefore suppose that the timing of the marine/brackish-lacustrine transition is also the timing of the final lake formation, which is dated to $8000 \mathrm{cal}$ yr BP for Lago Lanalhue and to $8150 \mathrm{cal}$ yr BP for Lago Lleu Lleu. Thus at those times the barriers that are nowadays impounding the lakes must have been uplifted and emerged above sea level, consequently separating the water bodies from the Pacific Ocean (Fig. 7B).

The surface topography of the barrier that blocks Lago Lanalhue shows a deep incision by the formerly westward flowing river Lanalhue', which left a rather oversized valley when compared with the small stream that is nowadays draining the lake (Fig. 3). Currently, this small stream is flowing on resistant crystalline basement (observable, for instance, where the highway P-70 is crossing the Lanalhue outlet; coordinates: $37^{\circ} 54^{\prime} 12^{\prime \prime} \mathrm{S}, 73^{\circ} 23^{\prime} 57^{\prime \prime} \mathrm{W}$ ), which lets us hypothesize that a change in the erodability of the swell-building material could have been jointly causative for the final lake formation as well. As long as the ancient river was flowing on the less resistant, poorly consolidated Pleistocene deposits of the Cañete terrace, it was incising the slowly uplifting swell and consequently maintaining a connection with the Pacific Ocean. When the river incised through the entire Cañete sequence reaching the underlying resistant basement, it was barely capable to further incise the uplifting barrier. As a result, the river was finally defeated and the lake impounded.

The sediments of both lakes remained of lacustrine character ever since the first blockage, indicating that both water bodies never had mixing contact with the ocean again. However, other environmental changes, as for instance variations in the regional climate, took place in the catchment areas and left their mark in the sedimentary records. Considering a modeling study of the longterm evolution of tectonic lakes proposed by Garcia-Castellanos (2006), Lago Lanalhue and Lago Lleu Lleu will most probably persist in the future as long as tectonic uplift of the barriers is holding up. Potentially, the lakes could even become full endorheic if either the uplift rate accelerates to completely defeat fluvial erosion of the swells, or if evaporation in the drainage basins becomes strong enough to completely outpace the erosive capacity of their fluvial outlets. If, however, the tectonic forcing tapers off at any time, an extinction of the lakes by sediment overfills and/or outlet erosion is predetermined.

\subsection{Calculation of local uplift rates}

The transitional layers, determined by both seismic and sedimentary analyses, mark the beginning (Transition 1) and the end (Transition 2) of the marine influence on the sedimentary deposition in the Lanalhue and Lleu Lleu systems. The comparison with the Holocene evolution of the global sea level hence allows for the calculation of local surface uplift rates. Therefore it is first necessary to assess the following parameters: I) the timing of the transitions, II) the present elevation ( $m$ a.s.l.) of the transitional layers, and III) the global sea-level at the time of the transitions.

The first two parameters (timing of the transitions and presentday elevation of the transitional layers) can be derived from the age model and the combination of water depth, actual elevation of the lake level, and thickness of the sedimentary sequence (assuming that there has not been sediment compaction). We calculated them for the master core sites, at which the depths of the transitional layers have an averaged, representative depth for the entire lake; resulting data are listed in Table 4. The third parameter (relative sea level, RSL), however, has to be necessarily taken from literature. This poses the problem that, especially when considering the Holocene time period, RSL curves are scarce and conspicuous differences between individual
Table 4

Parameters used for the calculation of uplift rates.

\begin{tabular}{lcc}
\hline & Lago Lanalhue (LA) & \multicolumn{1}{c}{ Lago Lleu Lleu (LL) } \\
\hline Timing of Transition 1 $\left(t_{1}\right)$ & $9200 \pm 70 \mathrm{cal} \mathrm{yr} \mathrm{BP}$ & $11250 \pm 55 \mathrm{cal} \mathrm{yr} \mathrm{BP}$ \\
Present-day elevation of the layer & $-23.25 \pm 1.44 \mathrm{~m}$ a.s.l. & $-47.22 \pm 1.44 \mathrm{~m}$ a.s.l. \\
$\left(h_{1}\right)^{\mathrm{a}}$ & & \\
Relative sea level (RSL) at $t_{1}{ }^{\mathrm{b}}$ & $-27.17 \pm 6.40 \mathrm{~m}$ a.s.l. & $-52.74 \pm 4.5 \mathrm{~m}$ a.s.l. \\
Timing of Transition 2 $\left(t_{2}\right)$ & $8000 \pm 50 \mathrm{cal} \mathrm{yr} \mathrm{BP}$ & $8150 \pm 96 \mathrm{cal} \mathrm{yr} \mathrm{BP}$ \\
Relative sea level (RSL) difference & $10.59 \pm 3.1 \mathrm{~m}$ & $35.23 \pm 1.43 \mathrm{~m}$ \\
$\left(t_{1}-t_{2}\right)^{\mathrm{b}}$ & &
\end{tabular}

${ }^{a}$ Calculated as: present-day elevation of lake level (LA: $8.0 \pm 1.44 \mathrm{~m}$ a.s.l.; LL: $5.0 \pm$ $1.44 \mathrm{~m}$ a.s.l) minus present-day water depth (LA: $18 \mathrm{~m}$; LL: $40 \mathrm{~m}$ ) minus thickness of the sedimentary sequence above the transitional layer (LA: $13.25 \mathrm{~m}$; LL: $12.22 \mathrm{~m}$ ).

b Calculated as: mean difference \pm standard deviation between the sea level at the time of Transition $1\left(t_{1}\right)$ and the sea level at the time of Transition $2\left(t_{2}\right)$, deduced from: Global stack (Fleming et al., 1998), Barbados (Fairbanks, 1989; Bard et al., 1990), Tahiti (Bard et al., 1996).

curves are apparent (e.g. Bassett et al., 2005; Milne et al., 2005; Caputo, 2007). Accordingly, even though the exact present-day altitude and the exact timing of the transition from marginal-marine to lacustrine conditions are known, the height of the past sea level is a relative uncertain factor. Hence the use of only one global sea level curve makes the calculated uplift rates tenuous. To reduce this uncertainty and to avoid any bias introduced by selecting a particular curve, we compiled several sea-level curves and calculated a range in the uplift rates according to the resulting values. In this regard, we implemented the sea-level records from Barbados (Fairbanks, 1989; Bard et al., 1990) and Tahiti (Bard et al., 1996), both based on fossil coral samples, as well as the global stack of sea-level curves of Fleming et al. (1998) (Fig. 8).

Based on these parameters, we calculate two different uplift rates: (I) a rate for the overall lake basins and (II) a rate for the barriers that are impounding the lakes and which must hence have experienced a stronger vertical deformation.

(I) When the valleys of the former rivers Lanalhue and Lleu Lleu were first flooded by the marine transgression at $9200 \mathrm{cal}$ yr BP and 11,250 cal yr BP, respectively, they must have been at the height of the global sea level. By means of known sea-level reconstructions, we can hence deduce the elevation of the river valleys at the time of Transition 1 and compare it to the present-day one. Accordingly, the uplift of the lake basins since the time of the first flooding can be calculated as follows:

uplift $\geq\left(h_{\text {Transition 1 }}-\right.$ sea level $\left.\operatorname{Transition~1~}\right) / t_{\text {Transition } 1}$

with $h_{\text {Transition } 1}=$ present elevation of the transitional layer ( $\mathrm{m}$ a.s.l.), sea level $_{\text {Transition 1 }}=$ RSL at the time of Transition 1, and $t_{\text {Transition 1 }}=$ timing of Transition 1. In the case of Lago Lanalhue, the uplift rate is $0.42 \pm$ $0.71 \mathrm{~mm} / \mathrm{a}$, whereas for Lago Lleu Lleu the rate is $0.49 \pm 0.44 \mathrm{~mm} / \mathrm{a}$ (inserted values listed in Table 4).

We have to admit an uncertainty concerning the water depth in which the lagoon sediments were deposited. To simplify matters, we assumed a deposition at mean sea level for the calculation above. However, since the sediments may have been deposited in some meters of water depth, it is to be considered that the calculated rates are only minimum estimates of uplift.

(II) For allowing the marine transgression to flood the former river valleys, the barriers that are nowadays impounding the lakes must have been at the height of, or slightly lower than the sea level. However, when the conditions changed from marginal marine to lacustrine, the barriers must have been elevated above sea level to truncate the systems from the Pacific Ocean and to let the lakes finally develop. As a result, the uplift of the barriers in the period between Transition 1 and Transition 2 must have been of a similar dimension 


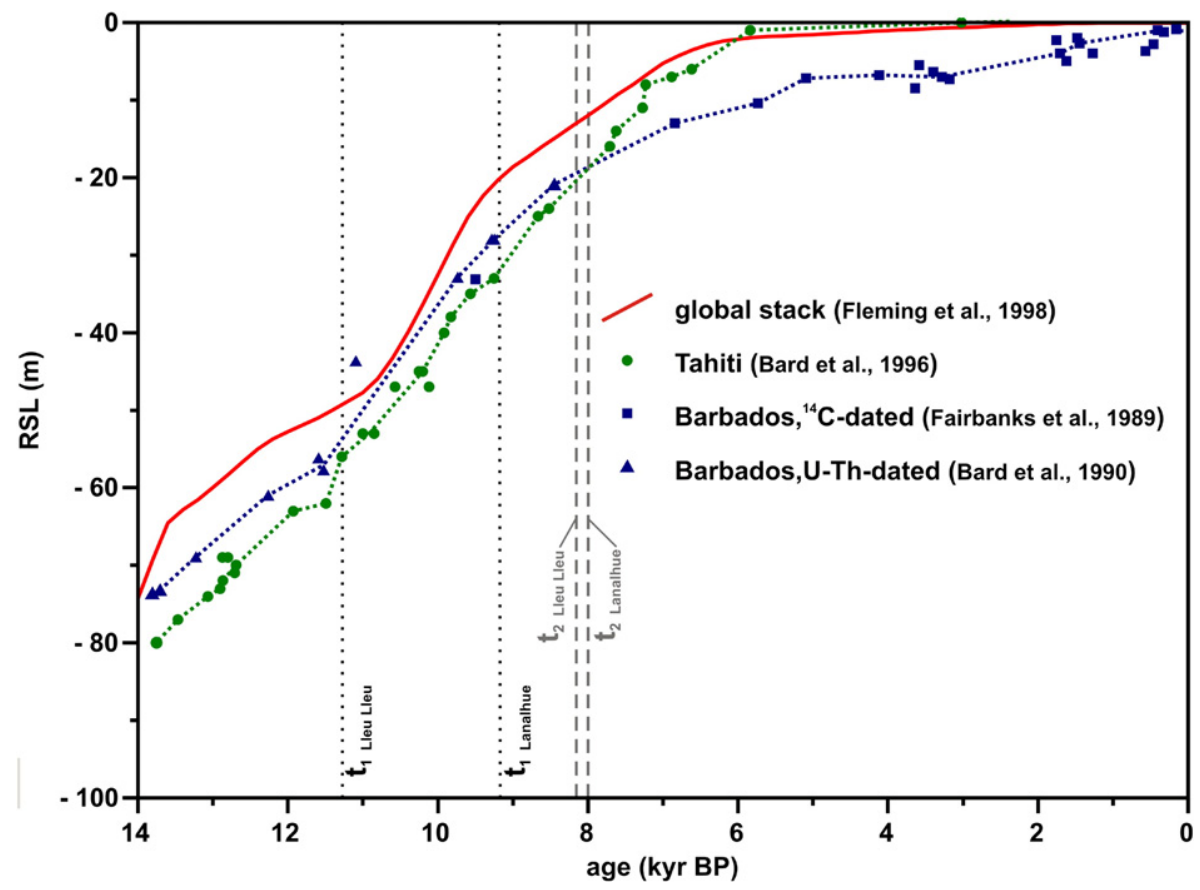

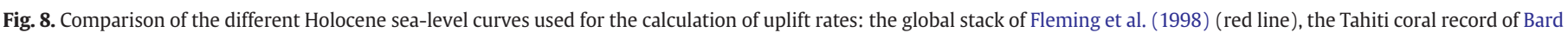

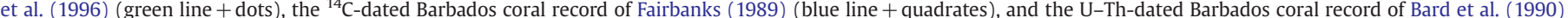
(blue line + triangles). The timing of Transition 1 ( $t_{1}$, black dotted line) and Transition 2 ( $t_{2}$, grey dashed line) is indicated for Lago Lanalhue and Lago Lleu Lleu, respectively.

as the increase of the global sea level. Therefore, their vertical deformation can be calculated as:

uplift $\geq\left(\right.$ sea level Transition 1 $_{1}-$ sea level $\left._{\text {Transition 2 }}\right) /\left(t_{\text {Transition 1 }}-t_{\text {Transition 2 }}\right)$

with sea level $\mathrm{Transition} \mathrm{1}_{1}=$ sea level at the time of Transition 1, and $t_{\text {Transition } 2}=$ timing of Transition 2 .

For this calculation it is necessary to keep in mind, that the barriers are also exposed to erosional processes, acting contrary to the local surface uplift. An additional element of uncertainty is that the barriers could have been located several meters below sea level at Transition 1 and several meters above sea level at Transition 2. Therefore, the calculated uplift rates can only be minimum estimates. For the barrier impounding Lago Lanalhue we obtained an uplift rate of $8.83 \pm$ $2.7 \mathrm{~mm} / \mathrm{a}$, whereas for the barrier impounding Lago Lleu Lleu a rate of $11.36 \pm 1.77 \mathrm{~mm} / \mathrm{a}$ was calculated (inserted values listed in Table 4).

\subsection{Uplift rates in the regional context}

A comparison of our data with independent uplift rates derived from emerged marine terraces and incision of fluvial terraces in the Arauco Peninsula region and adjacent Coastal Cordillera allows appraising the actual relevance of uplift rates derived from our novel approach. In general, differential uplift rates arose for the swells that are impounding the lakes and for the lake basins themselves. The calculated uplift rates for the lake basins of Lago Lanalhue $(0.42 \pm$ $0.71)$ and Lago Lleu Lleu $(0.49 \pm 0.44 \mathrm{~mm} / \mathrm{a})$ during the Holocene indeed have a large range. Nevertheless, they are basically coincident for both lakes and, furthermore, in good agreement with uplift rates calculated for the southern Arauco Peninsula. Melnick et al. (2009), for instance, determined uplift rates of $0.51 \pm 0.1 \mathrm{~mm} / \mathrm{a}$ since $\sim 125 \mathrm{ka}$, based on emerged marine terraces. Rehak et al. (2008) and Rehak et al. (submitted for publication) used incised fluvial terraces to calculate uplift rates ranging between 0.27 and $0.88 \mathrm{~mm} / \mathrm{a}$ since $\sim 80 \mathrm{ka}$. We hence believe our results to be reliable and conclude that in general uplift of the Arauco peninsula has not changed substantially during the Late Pleistocene and Holocene.

However, with rates of $8.83 \pm 2.7 \mathrm{~mm} / \mathrm{a}$ (Lago Lanalhue) and $11.36 \pm 1.77 \mathrm{~mm} / \mathrm{a}$ (Lago Lleu Lleu), uplift of the swells that are impounding the lakes is approximately 20 times higher than for the lake basins themselves. Unfortunately, it is not inferable from our data if these high rates of vertical deformation are temporally constricted to the time periods between 9200 to 8000 cal yr BP (Lago Lanalhue) and 11,250 to 8150 cal yr BP (Lago Lleu Lleu), or if they have been sustained since. Disregarding erosional processes and assuming that these uplift rates have been constant through the entire Holocene, the barriers would be at an altitude of $\sim 54 \mathrm{~m}$ a.s.l. (Lago Lanalhue) and $\sim 77 \mathrm{~m}$ a.s.l. (Lago Lleu Lleu) nowadays. Since they are situated distinctly lower, at $\sim 30 \mathrm{~m}$ a.s.l. for Lanalhue and at $\sim 25 \mathrm{~m}$ a.s.l. for Lleu Lleu, it is likely that their apparent extreme high uplift rates were transient. Taking the present barrier elevation as an opportunity to calculate the uplift of the barriers for the time period since $\sim 8 \mathrm{ka}$, we obtain rates of $3.75 \mathrm{~mm} / \mathrm{a}$ (for the Lanalhue barrier) and $3.07 \mathrm{~mm} / \mathrm{a}$ (for the Lleu Lleu barrier). Although these rates represent minimal amounts by which the swells must have been uplifted, they are still 7 times higher than the rates calculated for the lake basins.

The large vertical motion of the lake barriers may be a result of the eastward tilt of the Cañete terrace, which is affected by the Morguilla Fault. Despite the lack of clear field evidence of this fault, Melnick et al. (2009) interpret it as an active reverse fault based on seismological data (focal mechanisms), age determinations of deformed marine terraces and offshore reflection seismic lines. It is thought to be one of several active deep-reaching faults that are controlling uplift at the Arauco Peninsula with an associated cluster of crustal seismicity (Melnick et al., 2009). In its northwestern part, the fault is expressed as a pronounced escarpment of up to $150 \mathrm{~m}$ height, which decreases toward the southeast where it is hidden due to progressive blanketing by active dunes (Fig. 3). We suggest that the strong uplift of the Lanalhue and Lleu Lleu swells provides evidence for enhanced vertical deformation along the Morguilla Fault, and hence constitutes an 

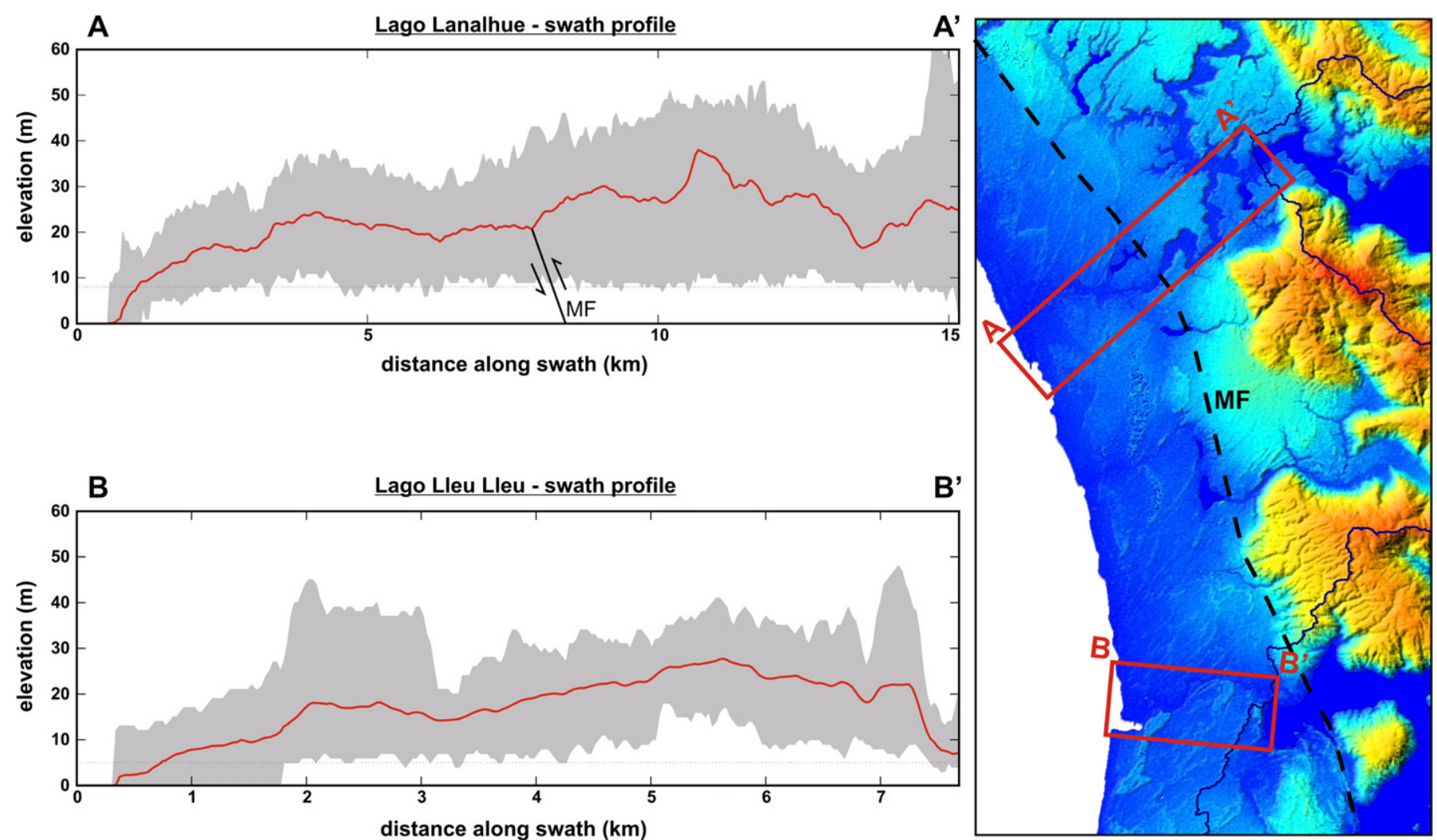

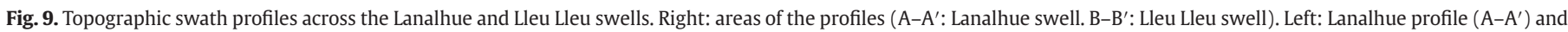
Lleu Lleu profile $\left(B-B^{\prime}\right)$. Each profile shows maximum, minimum (shading), and mean elevations (red solid line) of topography. MF $=$ Morguilla Fault.

indication of incipient exposure in its southern part as well. Topographic swath profiles spanning from the Pacific to the lake outlets exhibit cross-sections of the uplifted swells and allow identifying the approximate course of the fault (Fig. 9). Our interpretation is in line with a study of Rehak et al. (submitted for publication), who found a tectonically induced flow reversal of the formerly westward flowing Pellahuén River that is located directly south of Lago Lleu Lleu (Fig. 3). The authors suggest that the defeat of the river is controlled by local uplift above a blind reverse fault (Rehak et al., submitted for publication). According to our results, this is another indication for the southern prolongation of the active Morguilla Fault also controlling the formation of the two coastal lakes.

\section{Conclusions}

The sediments of Lago Lanalhue and Lago Lleu Lleu are excellent recorders of environmental changes. In the present study, we investigated the lake sediments with special emphasis on their capacity of giving information on local tectonics, in particular about surface uplift rates. We demonstrated that both lakes developed in former fluvial valleys, which became first lagoonal systems with a close connection to the Pacific Ocean, being subsequently separated from the ocean by tectonically upraised sills. The differing character of the sediments deposited during each of these phases, the dating of the transitions between the varying facies, and the overall comparison with the global seal level evolution, allowed calculating local uplift rates during the Holocene of $\sim 0.4 \mathrm{~mm} / \mathrm{a}$ for both lake basins.

So far, uplift rates of the Arauco Peninsula have been calculated on the base of emerged marine terraces that formed during the different interglacial stages of the Pleistocene. These rates hence constitute average long-term values over $10^{5}-10^{6}$ years. Our novel approach is the first attempt to achieve local deformation rates on shorter time scales of
$10^{3}-10^{4}$ years. The good agreement between the uplift rates calculated for the basins of Lago Lanalhue and Lago Lleu Lleu emphasizes the reliability of our approach. The comparison of our results with inferred tectonic structures in the Arauco region revealed new and detailed information about local forearc tectonics and distribution of active fault systems. On that account, we highlight the potential of sedimentary archives for the reconstruction of local tectonics.

\section{Acknowledgements}

We thank R. Kilian, M. Arevalo, A. Peña, and J. Jara for their professional and indispensable help in the field as well as for many fruitful discussions. The seismic data were collected with the help of K. De Rycker, F. Charlet, E. Chapron, A. Peña and W. San Martin. We further thank R. Urrutia (EULA, University of Concepción, Chile), M. Pino and R. Brümmer (Universidad Austral de Chile, Valdivia) for logistic support. We are grateful to Sven Nielsen for providing assistance with the identification of bivalves. We highly acknowledge the comments of two anonymous reviewers, which improved the manuscript. Research was financially supported by the Center for System Analysis of Geoprocesses CSAG), the DFG (Deutsche Forschungsgemeinschaft, German Reasearch Foundation), the Belgian Science Policy Office (BELSPO) and the Special Research Fund (BOF) of Ghent University. J. Moernaut acknowledges the support of the Institute for the Promotion of Innovation through Science and Technology in Flanders (IWT-Vlaanderen).

\section{References}

Abbott, L.D., Silver, E.A., Anderson, R.S., Smith, R., Ingles, J.C., Kling, S.A., Haig, D., Small, E., Galewsky, J., Silter, W., 1997. Measurement of tectonic surface uplift rate in a young collisional mountain belt. Nature 385, 501-507.

Anderson, R., Densmore, A., Ellist, M., 1999. The generation and degradation of marine terraces. Basin Research 11, 7-19. 
Angermann, D., Klotz, J., Reigber, C., 1999. Space-geodetic estimation of the NazcaSouth America Euler vector. Earth and Planetary Science Letters 171 (3), 329.

Antonioli, F., Ferranti, L., Lambeck, K., Kershaw, S., Verrubbi, V., Dai Pra, G., 2006. Late Pleistocene to Holocene record of changing uplift rates in southern Calabria and northeastern Sicily (southern Italy, Central Mediterranean Sea). Tectonophysics $422,23-40$.

Bangs, N., Cande, S.C., 1997. Episodic development of a convergent margin inferred from structures and processes along the southern Chile margin. Tectonics 16 , 489-503.

Bard, E., Hamelin, B., Fairbanks, R.G., Zindler, A., 1990. Calibration of the 14-C timescale over the past 30,000 years using mass spectrometric U-Th ages from Barbados corals. Nature 345, 405-409.

Bard, E., Hamelin, B., Arnold, M., Montaggioni, L., Cabioch, G., Faure, G., Rougerie, F., 1996. Deglacial sea-level record from Tahiti corals and the timing of global meltwater discharge. Nature 382, 241-244.

Bassett, S.E., Milne, G.A., Mitrovica, J.X., Clark, P.U., 2005. Ice sheet and solid Earth influences on far-field sea-level histories. Science 309, 925-928.

Becek, K., 2008. Investigating error structure of shuttle radar topography mission elevation data product. Geophysical Research Letters 35. doi:10.1029/2008GL034592L15403.

Bertrand, S., Charlet, F., Chapron, E., Fagel, N., De Batist, M., 2008. Reconstruction of the Holocene seismotectonic activity of the Southern Andes from seismites recorded in Lago Icalma, Chile, $39^{\circ} \mathrm{S}$. Paleogeography, Paleoclimatology, Paleoecology 259, 301-322.

Blumberg, S., Lamy, F., Arz, H.W., Echtler, H.P., Wiedicke, M., Haug, G.H., Oncken, O. 2008. Turbiditic trench deposits at the South-Chilean active margin: a PleistoceneHolocene record of climate and tectonics. Earth and Planetary Science Letters 268, 526-539.

Bohm, M., Lüth, S., Echtler, H., Asch, G., Bataille, K., Bruhn, C., Rietbrock, A., Wigger, P., 2002. The Southern Andes between $36^{\circ}$ and $40^{\circ} \mathrm{S}$ latitude: seismicity and average velocities. Tectonophysics 356, 275-289.

Bohm, M., 2004. 3-D local earthquake tomography of the southern Andes between $36^{\circ}$ and $40^{\circ} \mathrm{S}, \mathrm{PhD}$ thesis, $135 \mathrm{pp}$, Free University, Berlin, Germany

Bookhagen, B., Echtler, H.P., Melnick, D., Strecker, M.R., Spencer, J.Q.G., 2006. Using uplifted Holocene beach berms for paleoseismic analysis on the Santa María Island, south-central Chile. Geophysical Research Letters 33, L15302.

Börgel, R., 1953. Geomorfología. Geografía de Chile. InInstituto Geográfico Militar de Chile.

Bruhn, C., 2003. Momentensensoren hochfrequenter Ereignisse in Südchile, Ph.D. thesis, 181 pp, University of Potsdam, Potsdam.

Burbank, D.W., Anderson, R.S., 2001. Tectonic Geomorphology. Blackwell Science. 274 pp.

Caputo, R., 2007. Sea-level curves: perplexities of an end-user in morphotectonic applications. Global and Planetary Change 57, 417-423.

Cembrano, J., Lavenu, A., Reynolds, P., Arancibia, G., López, G., Sanhueza, A., 2002. Late Cenozoic transpressional ductile deformation north of the Nazca-South AmericaAntarctica triple junction. Tectonophysics, 354 (3-4), 289-314.

Chen, Y.-G., Liu, T.-K., 2000. Holocene uplift and subsidence along an active tectonic margin southwestern Taiwan. Quaternary Science Reviews 19, 923-930.

Cisternas, M., Atwater, B.F., Torrejón, F., Sawai, Y., Machuca, G., Lagos, M., Eipert, A., Youlton, C. Salgado, I, Kamataki, T, Shishikura, M., Rajendran, C. . Malik, JK, Rizal, Y., Husni, M. 2005. Predecessors of the giant 1960 Chile earthquake. Nature 437, 404-407.

Encinas, A., Hervé, F., Villa-Martinez, R., Nielsen, S., Finger, K.L., Peterson, D.E., 2006 Finding a Holocene marine layer in Algarrobo ( $33^{\circ} 22^{\prime} \mathrm{S}$ ), central Chile. Implications for coastal uplift. Revista Geologica de Chile 33 (2), 339-345.

Endlicher, W., Mäckel, R., 1985. Natural resources, land use and degradation in the coastal zone of Arauco and the Nahuelbuta Range, Central Chile. GeoJournal 11 (1), 43-60.

Fairbanks, R.G., 1989. A 17,000-year glacio-eustatic sea level record: influence of glacial meting rates on the Younger Dryas event and deep-ocean circulation. Nature 342,637-642.

Fleming, K., Johnston, P., Zwartz, D., Yokoyama, Y., Lambeck, K., Chappell, J., 1998 Refining the eustatic sea-level curve since the Last Glacial Maximum using far- and intermediate-field sites. Earth and Planetary Science Letters 163 (1-4), 327-342.

Garcia-Castellanos, D., 2006. Long-term evolution of tectonic lakes: climatic controls on the development of internally drained basins. Geological Society of America Special Paper 398, 283-294.

Glodny, J., Lohrmann, J., Echtler, H., Graefe, K., Seifert, W., Collao, S., Figueroa, O., 2005 Internal dynamics of a paleoaccretionary wedge: insights from combined isotope tectonochronology and sandbox modelling of the south-central Chilean forearc Earth and Planetary Science Letters 231 (1-2), 23-39.

Glodny, J., Echtler, H.P., Collao, S., Ardiles, M., Buron, P., Figueroa, O., 2008a. Differential Late Paleozoic active margin evolution in south-central Chile $\left(37^{\circ}-40^{\circ} \mathrm{S}\right)$ - the Lanalhue Fault Zone. Journal of South American Earth Sciences. doi:10.1016/j.jsames.2008.06.001.

Glodny, J., Gräfe, K., Echtler, H., Rosenau, M., 2008b. Mesozoic to Quaternary continental margin dynamics in south-central Chile $\left(36^{\circ}-42^{\circ} \mathrm{S}\right)$ : the apatite and zircon fission track perspective. International Journal of Earth Sciences 97 (6), 1271-1291.

Haberland, C., Rietbrock, A., Lange, D., Bataille, K., Hofmann, S., 2006. Interaction between forearc and oceanic plate at the south-central Chilean margin as seen in local seismic data. Geophysical Research Letters 33, L23302.

Hervé, F., 1988. Late Paleozoic subduction and accretion in Southern Chile. Episodes 11 $183-188$

Hervé, F., 1994. The Southern Andes between $39^{\circ}$ and $44^{\circ} \mathrm{S}$ latitude: the geological signature of a transpressive tectonic regime related to a magmatic arc. In: Reutter, K.--., Scheuber, E., Wigger, P. (Eds.), Tectonics of the Southern Central Andes. InSpringer, pp. 243-248.

Hsu, J.T., 1992. Quaternary uplift of the Peruvian coast related to the subduction of the Nazca Ridge: 13.5 to 15.6 degrees south latitude. Quaternary International 15 (16), 87-97.

Hughen, K.A., Baillie, M.G.L., Bard, E., Bayliss, A., Beck, J.W., Blackwell, P.G., Buck, C.E., Burr G.S., Cutler, K.B., Damon, P.E., Edwards, R.L., Fairbanks, R.G., Friedrich, M., Guilderson, T.P., Herring, C., Kromer, B., McCormac, F.G., Manning, S.W., Ramsey, C.B., Reimer, P.J.
Reimer, R.W., Remmele, S., Southon, J.R., Stuiver, M., Talamo, S., Taylor, F.W., van der Plicht, J., Weyhenmeyer, C.E., 2004a. Marine04 marine radiocarbon age calibration, 26-0 ka BP. Radiocarbon 46, 1059-1086.

Jordan, T.E., Burns, W.M., Veiga, R., Pangaro, F., Copeland, P., Kelley, S., Mpodozis, C., 2001. Extension and basin formation in the southern Andes caused by increased convergence rate: a mid-Cenozoic trigger for the Andes. Tectonics 20, 308-324.

Kaizuka, S., Matsuda, T., Nogami, M., Yonekura, N., 1973. Quaternary tectonic and recent seismic crustal movements in the Arauco Peninsula and its environs, Central Chile. Geographical Reports of Tokyo Metropolitan University 8, 1-49.

Keller, E.A., Pinter, N., 2002. Active Tectonics: Earthquakes, Uplift, and Landscape. Prentice Hall, Upper Saddle River, NJ.

Kendrick, E., Bevis, M., Smalley, R., Brooks, B., Vargas, R.B., Lauria, E., Fortes, L.P.S., 2003. The Nazca-South America Euler vector and its rate of change. Journal of South American Earth Sciences 16 (2), 125-131.

Lajoie, K., 1986. Coastal tectonics. Active Tectonics. Studies in Geophysics. InNational Academy Press, Washington D.C., USA.

Lomnitz, C., 1970. Major earthquakes and tsunamis in Chile during the period 1535 to 1955. Geologische Rundschau 59, 938-960.

Lomnitz, C., 2004. Major earthquakes of Chile: a historical survey, 1535-1960. Seismological Research Letters 75 (3), 368-378.

Mardones, M., Reuther, C.-D., 1999. Geomorphological aspects of the drainage pattern around Lake Lanalhue and Lake Lleulleu in the active convergent margin setting of south-central Chile. Mitteilungen Aus Dem Geologisch-Paläontologischen Institut Der Universität Hamburg 83, 75-88.

McCormac, F.G., Hogg, A.G., Blackwell, P.G., Buck, C.E., Higham, T.F.G., Reimer, P.J., 2004. SHCal04 southern hemisphere calibration 0-1000 cal BP. Radiocarbon 46, 1086-1092.

Melnick, D., Echtler, H.P., 2006a. Inversion of forearc basins in south-central Chile caused by rapid glacial age trench fill. Geology 34 (9), 709-712.

Melnick, D. and Echtler, H.P., 2006b. Morphotectonic and geologic digital map compilations of the south-central Andes $\left(36^{\circ}-42^{\circ} \mathrm{S}\right)$. In The Andes - Active Subduction Orogeny (ed. O. e. a. (Editors)), pp. 565-568. Springer-Verlag.

Melnick, D., Bookhagen, B., Echtler, H.P., Strecker, M.R., 2006. Coastal deformation and great subduction earthquakes, Isla Santa María, Chile $\left(37^{\circ} \mathrm{S}\right)$. Geological Society of America Bulletin 118 (11), 1463-1480

Melnick, D., Bookhagen, B., Strecker, M.R., Echtler, H.P., 2009. Segmentation of megathrust rupture zones from forearc deformation patterns over hundreds to millions of years, Arauco Peninsula, Chile. Journal of Geophysical Research 114, B01407.

Milne, G.A., Long, A.J., Bassett, S.E., 2005. Modelling Holocene relative sea-level observations from the Caribbean and South America. Quaternary Science Reviews $24,1183-1202$

Moernaut, J., De Batist, M., Charlet, F., Heirman, K., Chapron, E., Pino, M., Brümmer, R., Urrutia, R., 2007. Giant earthquakes in south-central Chile revealed by Holocene mass-wasting events in Lake Puyehue. Sedimentary Geology 195, 239-256.

Moreno, M.S., Klotz, J., Melnick, D., Echtler, H., Bataille, K., 2008. Active faulting and heterogeneous deformation across a megathrust segment boundary from GPS data, south central Chile $\left(36-39^{\circ} \mathrm{S}\right)$. Geochemistry, Geophysics, Geosystems 9, 012024.

Muñoz, J., Troncoso, R., Duhart, P., Crignola, P., Farmer, L., Stern, C.R., 2000. The relation of the mid-Tertiary coastal magmatic belt in south-central Chile to the late Oligocene increase in plate convergence. Revista Geologica de Chile 27 (2), 177-203.

Mpodozis, C., Ramos, V.A., 1989. The Andes of Chile and Argentina. In: Ericksen, G., Canas Pinochet, M., Reinemund, J. (Eds.), Geology of the Andes and its relation to hydrocarbon and mineral resources, vol. 11. Earth Science Series - Circum-Pacific Council of Energy and Mineral Resources, Houston TX, pp. 59-89.

Murray, J., 1991. Ecology and Palaeoecology of Benthic Foraminifera. Longman Scientific \& Technical.

Nelson, A.R., Manley, W.F., 1992. Holocene coseismic and aseismic uplift of Isla Mocha, south-central Chile. Quaternary International 15-16, 61-76.

Nelson, E., Forsythe, R., Arit, I., 1994. Ridge collision tectonics in terrane development. Journal of South American Earth Sciences 7, 271-278.

Rabassa, J., Clapperton, C., 1990. Quaternary glaciations of the Southern Andes. Quaternary Science Reviews, 9, 153-174.

Radtke, U., 1989. Marine Terrassen und Korallenriffe - Das Problem der quartären Meeresspiegelschwankungen erläutert an Fallstudien aus Chile, Argentinien und Barbados. InHeinrich-Heine-Universität Düsseldorf.

Rajendran, K., Rajendran, C.P., Earnest, A., Ravi Prasad, G.V., Dutta, K., Ray, D.K., Anu, R., 2008. Age estimates of coastal terraces in the Andaman and Nicobar Islands and their tectonic implications. Teconophysics 455, 53-60.

Rehak, K., Strecker, M., Echtler, H., 2008. Morphotectonic segmentation of an active forearc, $37^{\circ}-41^{\circ} \mathrm{S}$, Chile. Geomorphology $94,98-116$.

Rehak, K., Niedermann, S., Preusser, F., Strecker, M.R., Echtler, H.P., submitted for publication. Late Pleistocene landscape in south-central Chile constrained by luminescence and stable cosmogenic isotope dating. GSA Bulletin.

Rosenau, M., Melnick, D., Echtler, H., 2006. Kinematic constraints on intra-arc shear and strain partitioning in the Southern Andes between $38^{\circ} \mathrm{S}$ and $42^{\circ} \mathrm{S}$ latitude. Tectonics 25 (4), TC4013.

Stuiver, M., Reimer, P.J., Reimer, R.W., 2005. CALIB 5.0. [WWW program and documentation].

Tebbens, S.F., Cande, S.C., 1997. Southeast Pacific tectonic evolution from early Oligocene to present. Journal of Geophysical Research - Solid Earth 102 (B6), 12061-12084.

Telford, R.J., Heegaard, E., Birks, H.J.B., 2004. The intercept is a poor estimate of calibrated radiocarbon age. The Holocene 14 (2), 296-298.

Urrutia, R., Cisternas, M., Araneda, A., Retamal, O., Parra, O., 2000. Caracterización morfométrica y sedimentológica de cinco lagos costeros de la VIII Región, Chile. Revista Geográfica De Chile Terra Australis 45, 7-24. 